\title{
Sorunlar ve Beklentilerin Algılanmasında Kadın Mülteciler ve Sivil Toplum Kuruluşları'
}

\author{
Asuman ÖZG̈̈R-KEYSAN (https://orcid.org/0000-0002-5377-2114), Gender and Women's Studies \\ Programme, Middle East Technical University, Turkey; e-mail: asumanozgur@gmail.com
}

Burcu ŞENTÜRK (https://orcid.org/0000-0001-8469-1811), Department of Business Administration, Ege University, Turkey; e-mail: burcu.senturk@ege.edu.tr

\section{Female Refugees and NGOs in the Perception of Problems and Expectations ${ }^{2}$}

\begin{abstract}
Non-governmental organizations (NGOs) have recently started to play a more active role within the context of migration, dealing with the problems of immigrants extensively across the world. With the Syrian civil war outbreak, national and international NGOs have taken quick steps to operate in various refugee issues in Turkey actively. To date, various studies have been carried out that focus on the status, needs, and problems of Syrian refugees and the position and role of the NGOs in meeting these needs. The present study differs from the others. It aims to analyse the possible differences in the perception of problems of expectations of the refugees possibly existing between the NGOs and the Syrian female refugees. The research is drawn upon in-depth interviews conducted between May and October of 2018 with 83 Syrian refugee women and 64 NGO representatives from 14 NGOs located in Istanbul, Izmir, Konya, Adana, and Gaziantep. This study argues that there is a rift between the refugee women and the NGO representatives in the perception of problems of expectations of the refugees.
\end{abstract}

Keywords

JEL Classification Codes: $\quad$ I31, I38, J61. Turkey.
Non-governmental Organizations (NGOs), Syria, Refugee Women,

Tüm dünyada sivil toplum kuruluşları (STK) göç ve göçmenlerle ilgili konularda etkin olmaya başlamıştır. Suriye'deki iç savaş ile birlikte Türkiye'de ise, mülteci meselesinin çeşitli alanlarında aktif olarak faaliyet gösteren ulusal ve uluslararası STK'lar ortaya çıkmıştır. Bugüne dek, Suriyeli mültecilerin statü, ihtiyaç ve sorunlarına ve STK'ların bu ihtiyaçları karşılamadaki konumu ve rolüne eğilen çeşitli çalışmalar gerçekleştirilmiştir. Bu çalışma diğer çalışmalardan farklı olarak, İstanbul, İzmir, Konya, Adana ve Gaziantep'te yer alan 14 STK'dan 64 STK temsilcisi ve 83 Suriyeli mülteci kadın ile Mayıs-Ekim 2018 tarihleri arasında gerçekleştirilmiş derinlemesine görüşmelere dayanarak, mültecilere yönelik çalışma yapan STK'lar ve bu STK'lardan destek alan mülteci kadınların mülteci olmaya yönelik var olan sorunları algılama biçimleri arasındaki ilişkiyi analiz etmeyi hedeflemektedir.

I Bu çalışma TÜBİTAK tarafindan desteklenen 217K337 numaralı "Türkiye'deki Sivil Toplum Kuruluşlarının Kadınlara Yönelik Güçlendirme Politikalart: Suriyeli Göçmen Kadınların Deneyimleri” adlı projeden üretilmiştir.

2 This study is derived from the project is supported by The Scientific and Technological Research Council of Turkey (Project No: 217K337) Women's Empowerment Policies of Civil Society Organisations in Turkey: Experiences of Syrian Female Migrants. 
Çalışma STK'lar ile mülteci kadınların sorunları algılamasında bir makas bulunduğunu savunmaktadır.

Anahtar Sözcükler $\quad$ : Sivil Toplum Kuruluşları (STK), Suriye, Mülteci Kadınlar, Türkiye.

\section{Giriş}

Türkiye, coğrafi konumu nedeniyle ve tarihsel olarak bakıldığında sıklıkla kitlesel göç almış bir ülkedir. İran İslam Devrimi, Kuzey Irak'ta yaşanan Halepçe Katliamı, Sovyet - Afgan Savaşı, Bulgaristan'da Jivkov rejiminin asimilasyon politikaları, Körfez Savaşı ve sonrasında Bosna, Kosova ve Makedonya'da yaşanan savaş sebebiyle birçok insan Türkiye'ye göç etmek zorunda kalmıştır (Göç İdaresi Genel Müdürlüğü, 2015). Nisan 2011 'den bu yana Suriye'de rejime karşı yürütülen savaş sonrasında savaş koşullarından kaçan yaklaşık 4,8 milyon insan Suriye'den çoğu Orta Doğu olmak üzere birçok ülkeye göç etmiştir (Todd, 2019). Çatışmadan kaçan Suriyelilerin \%83'ü Suriye sınırındaki ülkelere (Türkiye, Irak, Ürdün, Lübnan) göç etmiştir. Birleşmiş, Milletler Mülteciler Yüksek Komiserliği (BMMYK) dünyanın son 20 yılda görmüş, olduğu en yoğun insan hareketliliğiyle karşı karşıyadır. Tüm göçmenlerin yarısını kadınlar oluşturmaktadır (Kelson vd., 1999: 2). 2011 yılından bu yana Suriye'den yaşanan kitlesel göçle, Türkiye'deki kayıtlı Suriyeli göçmen sayısı 30 Nisan 2020 tarihi itibariyle 3.580.263'e ulaşmış ve kadın mülteciler bu mültecilerin yarısını oluşturmaktadır (Göç İdaresi Genel Müdürlüğü, 2020). Suriyeli mültecilerin ülkede sayısal artışıyla beraber küresel bir trend olarak, mülteci sorunuyla ilgili olarak ulusal ve uluslararası STK'lar ortaya çıkmış ve bu kuruluşlar mülteci meselesinin çeşitli alanlarında aktif olarak faaliyet göstermeye başlamış ve sorunların çözümünde önemli bir aktör haline gelmişlerdir (Keysan, 2020b; İGAM, 2013).

Özellikle 2000 sonrasında STK ve göç ilişkisine odaklanmış birçok çalışma bulunmakta ve bu çalışmaların önemli bir kesimini sivil toplum örgütlerinin göç alanındaki rolü ve etkisine odaklanan araştırmalar oluşturmaktadır. Söz konusu çalışmalar arasında, sivil toplum örgütlerinin devlet, göç politikaları (Geddes, 2003), ve uluslararası göç politikaları geliştirme üzerindeki etkisi (Lester, 2005), sivil toplumun mültecilere hizmet sağlama fonksiyonu ve bunun göçmen yönetişimi ve sosyal uyum açısından rolü ve etkisi (Sun \& Cadge, 2013; Ambrosini, 2013a, 2013b, 2015; İGAM, 2013: 3; Kutlu, 2015; Eastman, 2012; Tobin \& Campbell, 2016; Douglas vd., 2017: 34; Mackreath \& Sağnıç, 2017; Çebi, 2017; Sunata \& Tosun, 2018; Aslan \& Yılmaz, 2019) ile sivil toplumda insanî yardım ve hayırseverlik (Malkki, 2015; Piotukh, 2015; Hyndman, 2000; Aksürmeli \& Tekten, 2016; Ihlamur-Öner, 2012) konuları üzerine yoğunlaşan çeşitli çalışmalar yer almaktadır. Aynı şekilde, Suriyeli mültecilerin statü, ihtiyaç ve sorunlarına eğilen birçok çalışma da bulunmaktadır (Cankurtaran \& Albayrak, 2019; Öztürk vd., 2019; BM Kadın Birimi ve SGDD, 2018; AFAD, 2014; Mazlumder, 2014; KAMER, 2013; Al-Rousan vd., 2018; Herwig, 2017; Yenilmez, 2017; Sijbrandi vd., 2017; Kıv1lcım, 2016; Barın 2015; Erden 2016). Fakat mültecilerin sorunlarının iki farklı grup olan STK'lar ve sürecin aktörleri 
Özgür-Keysan, A. \& B. Şentürk (2021), "Sorunlar ve Beklentilerin Algılanmasında

Kadın Mülteciler ve Sivil Toplum Kuruluşları”, Sosyoekonomi, 29(48), 343-376.

olan mülteciler- kadınlar- tarafından hangi şekillerde algılandığına dair çok kısıtlı sayıda çalışma bulunmaktadır (Tomlinson \& Egan, 2002; Szczepanikova, 2010).

Bu çalışma mültecilere, özelde ise kadın mültecilere yönelik çalışma yapan STK'lar ve bu STK'lardan destek alan mülteci kadınların mülteci olmaya yönelik var olan sorunları algılama biçimleri arasındaki ilişkiye odaklanmaktadır. Böylece mülteci meselesi çerçevesinde yaşanan sorunların iki farklı grup tarafından algılanma biçimlerini ortaya koyarak sorunsallaştırmayı hedeflemektedir. Diğer bir deyişle, bu araştırma ile, STK'ların Suriyeli kadınların sorunları ve deneyimlerine yönelik algılarıyla söz konusu STK'lardan destek alan kadınların deneyimleri ve algıları karşılaştırılacak, kadınların yaşadıkları sorunlara ne ölçüde ve hangi şekillerde karşılık verdikleri sorularına hem Suriyeli kadınların hem de STK temsilcilerinin seslerine odaklanarak yanıt aranacaktır.

Çalışma kapsamında, İstanbul, İzmir, Konya, Adana ve Gaziantep olmak üzere Türkiye'nin beş ayrı ilinde 64 STK temsilcisi ve 83 Suriyeli mülteci kadın ile Mayıs-Ekim 2018 tarihleri arasında gerçekleştirilen derinlemesine görüşmelerin analizine dayanmaktadır. İki taraflı toplanan veriye dayanan bu çalışmada ilk olarak Türkiye'de şehirlerde yaşayan mülteci kadınların kendi sorun, ihtiyaç ve beklentilerini tanımlama biçimleri tespit edilecek, sonrasında ilgili konuda çalışan STK'ların mültecilerin sorun ve beklentilerini algılama biçimleri ortaya konularak STK'lar ve mültecilerin problem tanımlarının ne ölçüde ve hangi şekillerde birbiri ile örtüşüp/örtüşmediği değerlendirilecektir. Ortaya çıkan sonuçlar özellikle homojen bir kitle olmayan mülteci kadınların demografik özelliklerinin sorunları tanımlamada etkili olduğunu ancak bunun yanı sıra var olan sorunların önemli bir kısmının ekonomik sorunlar şemsiyesi altında toplanabileceğini işaret etmektedir. Bu durum, STK'lar ile mülteci kadınların sorunları algılamasında bir makas bulunduğunu, STK'ların ekonomik ihtiyaçları karşılamanın dışında sundukları hizmetlere rağmen önemli ölçüde maddi ihtiyaçların karşılanmasında başvurulan birimler olarak görüldüğünü ortaya koymaktadır.

\section{Göç, Sivil Toplum Örgütleri ve Toplumsal Cinsiyet}

Sivil toplumun göç ile olan ilişkisi üzerine olan literatür, genel sivil toplum literatürü ile kıyaslandığında yeni bir alandır. Ambrosini ve Van der Leun (2015: 108)'un ifade ettiği gibi, sivil toplumun devletin göç politikaları üzerindeki uyum, çatışma ve değiştirme yönünde bir etken olarak rol alması üzerine birçok çalışma bulunurken (Geddes, 2003), sivil toplumun özellikle yerel ve ulusal düzeyde hizmet sağlama fonksiyonunun yeterince incelenmediği vurgulanmaktadır (Sun \& Cadge, 2013; Ambrosini, 2013b). Başka bir deyişle, sivil toplum örgütlerinin göçmenler için ne tarz hizmetler sundukları, bu hizmetlerin farklı coğrafyalarda nasıl gerçekleştirildiği ve hatta STK'ların her koşulda göçmenleri destekleyip/desteklemediği soruları üzerine düşünülmesi gereken sorular olarak karşımıza çıkmaktadır (Eastman, 2012; Ambrosini, 2013a). Bu noktada, Ambrosini (2015)'nin İtalya'da düzensiz göçmenlere sağlanan sağlık hizmetleri ve STK'ların oynadığı rol ve Joanne Van der Leun ve Harmen Bouter (2015)'in Hollanda'da devletin dışlayıcı politikalarına karşın STK'ların düzensiz göçmenler için barınma erişimi konusunda 
Özgür-Keysan, A. \& B. Şentürk (2021), "Sorunlar ve Beklentilerin Algılanmasında

Kadın Mülteciler ve Sivil Toplum Kuruluşları”, Sosyoekonomi, 29(48), 343-376.

gerçekleştirdikleri faaliyetlere odaklanan çalışmaları bu alana katkı sağlamaktadır. Türkiye'deki sivil toplumun mültecilere hizmet sağlama fonksiyonu ve bunun göçmen yönetişimi ve sosyal uyum açısından rolü ve etkisi üzerine olan çalışmalar da önemlidir (İGAM, 2013: 3; Kutlu, 2015; Eastman, 2012; Erdoğan, 2015; Mackreath \& Sağnıç, 2017; Çebi, 2017; Sunata \& Tosun, 2018; Aslan \& Yılmaz, 2019). Bunlar arasında Kutlu (2015), Mackreath \& Sağnıç (2017) ve IGAM'ın çalışmaları, Türkiye'de kamp dışında belli metropol illerde yaşayan Suriyeli göçmenlere destek veren STK'ların yürüttükleri çalışmaların kısa bir dökümünü yapmakta ve Suriyeli göçmenlere yönelik olarak faaliyet gösteren STK'lar arasındaki genel bir iletişim ağının eksikliğine, STK'larda insan kaynaklarının çoğu zaman yetersiz kalışına ve özellikle hibe ve fonlarla çalışmalarını sürdüren STK'ların bu alandaki desteklerinin gün geçtikçe azalmasına ve istikrarlı olmamasına dikkat çekmektedir (Kutlu, 2015: 24-25; İGAM, 2013). Sosyal uyum konusuna odaklanmış olan Erdoğan (2015)'ın çalışmasının en önemli bulgusu ise Türkiye'ye sığınan Suriyeliler konusunda toplumsal kabul düzeyinin son derece yüksek olduğu fakat sürecin iyi yönetilmemesi durumunda bugüne kadar var olan toplumsal kabulün hızla olumsuz bir noktaya dönüşme riskinin varlığıdır (Erdoğan, 2015: 207). Çalışmada STK'ların sürecin içine çekilmesi, yaşanan krizin çözümü ve sivil toplumun gelişimi bakımından önemli olduğu vurgulanmıştır (Erdoğan, 2015a: 341). Benzer bir şekilde Çebi (2017: 136) inanç temelli STK'ların Suriyeliler ve Türkiyeliler arasındaki önemli farklılıkların yaratacağı problemleri en aza indirmede hayati bir öneme sahip olduğunun altını çizmiştir.

Göç alanında faaliyet gösteren STK'lar, 1980 sonrası ortaya çıkan diğer birçok STK gibi, sosyal devletin çöküşü ve neoliberalizmin yükselişi ile sosyal hizmet sunan ve gündelik pratikler üzerinde büyük etkiler bırakan yapılar olarak tanımlanmaktadır. Akbaş (2012: 339), göçmen sivil toplum örgütlerinin özellikle 2000'li yıllardan sonra sosyal hizmet projeleri üretmeye başlamaları ile bu kuruluşların sunduğu hizmet ve faaliyetlerin alanının aktörlerinin gündelik pratiğini etkileyen veya şekillendiren yapılar olarak oldukça büyük bir etki yarattığını savunur. Diğer bir deyişle, Akbaş (2012: 337) sivil toplum örgütlerini "devletin sosyal alandan çekilişiyle birlikte ortaya çıkan sosyal hizmet sunan ve tasarlayan yapılar" olarak tanımlar. Ambrosini ve Van der Leun (2015: 103) ise, sivil toplumun hem devlet politikalarına destek hem de belli ölçülerde tepki olarak göçmenlerin varlığına ve ihtiyaçlarına cevap vermeye çalıştığını savunur. Özellikle kamp dışında yaşayan mülteci sayılarında yaşanan artış sonucunda, sivil toplum kuruluşlarının mülteci grupları tanımlamak, onlarla görüşmeler gerçekleştirmek ve ihtiyaçlarını belirlemek noktasında çok kritik bir rol oynadığının altı çizilir (Douglas vd., 2017: 34). Örneğin, STK'lar göçmenlere, yasal olarak muğlak statüde olanlara hukuki destek, hizmet desteği, insan hakları desteği, finansal destek ve yerel kültür ve kurumlar üzerine içeriden bilgi sağlama desteği sunmaktadır (Laubenthal, 2007; Nicholls, 2013; Eastman, 2012; Aras \& Duman, 2018). Bu bağlamda, sivil toplumun göçmen yönetişimi noktasındaki önemi ve farklı coğrafyalarda bu yönetişimin aldığı biçimin ve toplumsal uyuma etkisinin de gözden kaçırılmaması gerektiği vurgulanmaktadır (Ambrosini \& Van der Leun, 2015: 110; Mackreath \& Sağnıç, 2017; Çebi, 2017; Sunata \& Tosun, 2018; Aslan \& Y1lmaz, 2019). 
Özgür-Keysan, A. \& B. Şentürk (2021), "Sorunlar ve Beklentilerin Algılanmasında

Kadın Mülteciler ve Sivil Toplum Kurulușları”, Sosyoekonomi, 29(48), 343-376.

Göç alanında çalışan sivil toplum kuruluşları arasında insani yardım temelli çalışan STK'ların sayıca fazlalığı, insani yardım kavramının değişimini beraberinde getirmiştir. Kriz dönemlerinde gıda, barınma gibi temel ihtiyaçların giderilmesi olarak başlayan insani yardım, daha sonra insanların üretken özneler haline gelmesi ve üretime katılmasını sağlayacak şekilde dönüşüm geçirmiştir. Özellikle mesleki eğitimlerle insanların üretime katılmasını sağlamak veya psiko-sosyal destek sunmak da bu kapsama girmeye başlamıştır (BM, t.y.). Öte yandan, insani yardım alanında ve bu temelde faaliyet yürüten STK'ların niceliksel fazlalığı, dolayısıyla hayırseverliğin ön plana çıktığını da göstermektedir (Malkki, 1996; Piotukh, 2015; Hyndman, 2000). Bu bağlamda, insani yardım kuruluşlarının içinde inanç temelli yardım kuruluşlarının en büyük payı oluşturması, sayı ve oynadıkları rol açısından artan rolleri neoliberal politikaların yarattığı etkinin bir sonucu olarak yorumlanmakta ve devlete alternatif ya da tamamlayıcı olarak görev üstlendiklerinin altı çizilmektedir (Aksürmeli \& Tekten, 2016: 351). Ihlamur Öner (2012: 310), inanç temelli yardım kuruluşları yerine dini kuruluşlar kavramını kullanmakta ve bu kuruluş ve ağların dini liderler aracılığıyla göçmenlik konusunda temel aktörler olarak faaliyet gösterdiklerine işaret etmektedir (bkz Rosenow-Williams \& Sezgin, 2014; Özkan, 2012; Eghdamian, 2016).

Bu çalışmanın önemli ayaklarından birisi olan göç ve kadın ilişkisi üzerine var olan literatür gittikçe önem kazanmaktadır. Bu alanda yaptıkları çalışmalarla dikkat çeken Castle, Haas ve Miller, İkinci Dünya Savaşı'ndan sonraki dönemi göçler çağı olarak adlandırmış, bu çağın önemli özelliklerinden biri olarak da göçün kadınlaşmasından bahsetmişlerdir (Castle vd., 2014). Günümüzde tüm göçmenlerin yarısını kadınlar oluşturmaktadır (Kelson vd., 1999: 2). Erkeklerin göç deneyimini merkeze alan, kadınların göç deneyimini görmezden gelen ana akım göç literatürü, kadınları ya erkeklere bağımlı aktörler ya da göçü hane kararı olarak görmekte, kadınların eyleyiciliğini (agency) görünmez kılmaktadır. Oysa son yıllarda giderek artan göçmen kadın sayısı, göçün değişen niteliğini de göstermektedir. $\mathrm{Bu}$ noktada, göçün kadınlaşması bize sadece artan kadın göçmen sayısını değil, aynı zamanda kadın ve erkek göçmenler arasında farklılaşan toplumsal cinsiyet deneyimlerini görmek için de önemli bir olanak sağlamakta, göçmen kadınların kendi aralarındaki heterojenliğe işaret ederek, kadınların artan eyleyiciliklerine odaklanmamızı da mümkün kılmaktadır (Koffman vd., 2005: 3). Bu bağlamda, feminist tartışmaların bir kısmı mülteci kadınların kırılgan ve mağdur pozisyonuna vurgu yaparak karşılaştıkları cinsel istismar ve şiddete işaret ederken (Friedman, 1992), bir kısmı ise "yerinden edilme/göç" ile değişen toplumsal cinsiyet rollerine yaptıkları vurgu ile (Daley, 1991), göçü kadınlar için özgürleştirici, değiştirici/dönüştürücü bir eylem olarak kavramsallaştırmaktadırlar (Boserup, 1970; Pedraza, 1991). Göç hareketlerini incelemeye dönük literatürdeki odak değişimi feminist perspektif ve yöntem doğrultusunda meseleyi ele alan çalışmalar içinde alan açmıştır. Örneğin Türkiye'deki iç göçle ilgili bu perspektifle çalışan Erman (2014) ve Çınar (1994) kadın göçmenlerin iş piyasasına girme kararlarını ve tutumlarını, Şentürk (2015) göç kararı verme aşamasında kadınların ve erkeklerin birbirinden farklı motivasyonlarla hareket ettiklerini ve Wedel (2001) siyasal tercihlerinin nasıl farklılaştığını araştırmıştır. Uluslararası göç üzerine odaklanan yine benzer perspektifle yola çıkan çalışmalara bakıldığında ise gelinen yerde kalma süresinin kadınların eğitim ve iş hayatına katılımına 
Özgür-Keysan, A. \& B. Şentürk (2021), "Sorunlar ve Beklentilerin Algılanmasında

Kadın Mülteciler ve Sivil Toplum Kuruluşları”, Sosyoekonomi, 29(48), 343-376.

dair ataerkil değerleri yumuşattığını ve göçmen nesilleri arasında farklılıklar yarattığını (Qin, 2006; Nesteruk vd., 2009), kadın ve erkek göçmenlerin küresel iş piyasalarından nasıl farklı etkilendiğini (Phizacklea, 1998), ve iç göç kadar dış göçte de kadınlar ve erkeklerin göç kararını farklı faktörlerle aldığını (Boyd \& Grieco, 2003; Bastia 2019) araştırarak ana akım göç kuram ve araştırma yöntemlerini sorgulamaya açmıştır.

Genelde STK'ların çalışmaları ve yardımları temel ihtiyaçlara yönelik olsa da özel ihtiyacı olan gruplara örneğin engellilere, kadınlara yönelik çalışan az sayıda da olsa STK mevcuttur (Kutlu, 2015: 24). Bu STK'lar, araştırma kurumları ve bir takım platformlar kadınların sorun ve deneyimlerini anlamaya yönelmiş, raporlar yayınlamış ve gündem ve aktivitelerini bu doğrultuda şekillendirmeye başlamışlardır (Körükmez vd., 2020; Cankurtaran \& Albayrak, 2019; BM Kadın Birimi ve SGDD, 2018; Mazlumder, 2014; KAMER, 2013). Örneğin BM Kadın Birimi ve SGDD (2018: 6-7)'ın çalışması bize Suriyeli kadınlara özellikle barınma olanaklarına erişim, dil engeli ve istihdama erişim konularında kendilerine daha az firsat sunulduğunu göstermektedir. Aynı zamanda çalışmada yer alan Suriyeli kadınlar "başta sağlık olmak üzere hizmetlere erişimden memnun olduklarını ancak kendilerine sağlanabilecek desteklerin bütünü konusunda bilgi eksikliği yaşadıklarını ortaya ife etmişlerdir” (BM Kadın Birimi ve SGDD, 2018: 7).

Özellikle uluslararası kuruluşların sağladığg fonlarla birlikte STK'ların dilinde kadın güçlenmesi kavramı çok sıklıkla kullanılmaya ve STK'lar tarafından mültecileri, özellikle kadınları, güçlendirme politikaları uygulanmaya başlanmıştır (Lau, 2019; Elbers vd., 2014; Özgür-Keysan \& Şentürk, 2020a). Fakat mültecilerin sorunlarının iki farklı grup olan STK'lar ve sürecin aktörleri olan mülteci kadınlar tarafından hangi şekillerde algılandığına dair kısıtlı sayıda çalışma bulunmaktadır (Tomlinson \& Egan, 2002; Szczepanikova, 2010). Tomlinson ve Egan (2002)'ın mültecilere istihdamla ilgili hizmetler sunan kuruluşlara odaklanan çalışması, mültecilerin güçlendirme süreçlerinin ayrı bir mülteci kimliğini sürdürmeme durumunu tahrip edebildiği için sorunlu bir hal alabildiğini tartışmaktadır. Szczepanikova (2010) ise, STK'ların mültecileri pasif ajanlar olarak konumlandırarak mültecilerin güçlendirilmesi noktasında yetersiz kaldığını vurgulamaktadır.

Bu çalışma kısıtlı sayıda yer alan çalışmalara katkı sunacak şekilde mültecilere, özelde ise kadın mültecilere yönelik çalışma yapan STK'lar ve bu STK'lardan destek alan mülteci kadınların mülteci olmaya yönelik var olan sorunları algılama biçimleri arasındaki ilişkiye odaklanacaktır.

\section{Metodoloji ve Örneklem}

Bu çalışma feminist araştırma yöntemlerine dayanmakta ve bu doğrultuda sesleri duyulmayan kadınların deneyimlerini duyurmayı hedeflemektedir. Feminist yöntem, sosyal bilimlerde konunun ele alınma biçimi temelinden yükselerek, bir dizi birbiriyle yakından ilişkili olan soru sorma, veri toplama, araştırma etiği, sonuçların yazımı, paylaşımı ve kullanımını kapsar (Letherby, 2003). Söz konusu yöntem içinde özellikle veri toplama sürecinde farklı yaklaşımlara rastlansa da yöntemin temel noktası sesleri duyulmayan 
Özgür-Keysan, A. \& B. Şentürk (2021), "Sorunlar ve Beklentilerin Algılanmasında

Kadın Mülteciler ve Sivil Toplum Kurulușları”, Sosyoekonomi, 29(48), 343-376.

kadınların deneyimlerini duyulur/görünür kılmaya çalışmak, cinsiyetin sınıfsal, ırksal, etnik baskılar gibi diğer baskı türleri ile ilişkilendirerek tahakküm ilişkilerinde ezilenlerin lehine bilgi üretmektir (Maynard, 1994, Wolf, 1996; Letherby, 2003). Bu çalışma kapsamında feminist yöntem araştırma sorusu ilgili grubun sesini duyurma hedefiyle oluşturulmuş ve kadınların deneyimleri çalışmanın odağına konulmuştur. Veri toplama tekniği olarak ise ilgili grubun deneyimlerinin görünürlüğünü arttıracak şekilde derinlemesine mülakat tekniği kullanılmıştır.

Araştırmanın saha çalışması için kentli Suriyeli göçmen nüfusunun yoğun olduğu, Türkiye'de farklı demografik yapılara ve göç özelliklerine sahip, ekonomik gelişmişliğin farklı olduğu, etnik açılardan farklılıklar gösteren, göçmenlere yönelik STK faaliyetlerinin yoğun olarak yürütüldüğü ve Türkiye'nin 5 coğrafi bölgesini temsil eden İstanbul, İzmir, Adana, Konya ve Gaziantep şehirleri seçilmiştir. STK'ların web sayfaları var olan raporlar, çalışmalar ve haberler üzerinden yapılmış olan ön çalışma sonucunda bu şehirlerde Suriyeli mülteci kadınlara yönelik faaliyet gösteren 14 STK seçilmiştir. Her bir dernekten çeşitliliği korumak adına farklı pozisyonlarda yer alan dernek çalışanı (örneğin dernek başkanı, psikolog, öğretmen, taşıma sorumlusu, teknisyen, sosyal hizmet uzmanı vb.) ve gönüllülerle ve aynı zamanda derneğin hizmetlerinden yararlanan Suriyeli kadınlarla görüşmeler gerçekleştirilmiştir. Çalışma çerçevesinde söz konusu beş şehirde mülteci kadınlara yönelik faaliyet yürüten 14 STK'da gönüllü ya da profesyonel olarak çalışan 61 kişiyle ve bu STK'lardan hizmet alan 83 kişiyle görüşmeler yapılmıştır (Tablo 1). Çalışma kapsamında STK'lar ve Suriyeli mülteci kadınlarla görüşme yapmak için Göç İdaresi Genel Müdürlüğü'nden destek mektubu temin edilmiş, çalışmanın kapsam ve amaçları ODTÜ İnsan Araştırmaları Etik Kurulu tarafindan uygun bulunmuştur.

STK temsilcileriyle yapılan görüşmelerin tümü ve mültecilerle yapılan görüşmelerin tamamına yakını ilgili kurumların mekânında gerçekleştirilirken, Cansuyu Yardımlaşma ve Dayanışma Derneği'nin koordine ettiği Suriyeli kadınlarla yapılan görüşmeler kadınların evlerinde gerçekleştirilmiştir. STK temsilcileriyle yapılan görüşmeler, görüşülenlerin izni alınarak, ses kayıt cihazına kaydedilmiştir ve araştırmacılar tarafından çözümlenmiştir. Mülteci kadınlarla yapılan görüşmelerde ses kaydı alınmamış olup, tercüman eşliğinde gerçekleştirilmiştir. Gerçekleştirilen tüm derinlemesine görüşmeler deşifre edildikten sonra MAXQDA 2020 programı yardımıyla ayrıntılı olarak kodlanmış ve görüşme analizinde yararlanılacak temel değişkenler belirlenmiştir.

Suriyeli mülteci kadınlara hizmet veren STK'lara, dernek ve çalışan/gönüllülerine yönelik bilgiler, hedef ve ilkeleri, devlet kurumları, uluslararası kuruluşlar ve diğer STK'lar ile ilişkileri, ulusal ve uluslararası kaynaklardan fon alıp/almadıkları, faaliyetleri (genel ve kadınlar özelinde), faaliyet yürüttükleri kadınlara ulaşma biçimleri, Suriyeli kadınların Türkiye'de karşılaştığı sorunları nasıl tanımladıkları ve bu sorunların çözümünde kendilerini nerede konumlandırdıkları ve bu alanda çalışan bir STK olarak ihtiyaçları ve karşılaştıkları zorluklara yönelik sorular yöneltilmiştir. Görüşmeler, görüşülenlerin izni alınarak, ses kayıt cihazına kaydedilmiş ve görüşmeler yaklaşık olarak 40-90 dakika arasında sürmüştür. Ayrıca, görüşme yapılan STK'lardan broşür ve tanıtıcı dokümanlar toplanmıştır. 
Sivil toplum kuruluşlarından destek alan Suriyeli mülteci kadınlarla yapılan görüşmelerde kadınlara, demografik ve sosyoekonomik yapıya yönelik sorular, kaç yıldır Türkiye'de oldukları, geldiklerinden bu yana nerelerde yaşadıkları, gündelik pratikleri, göçmenlere yönelik olarak faaliyet gösteren STK'lar ile ilişkileri, STK'ların sağladıkları hizmetleri nasıl değerlendirdikleri, Türkiye'de yaşadıkları zorluklar ve ihtiyaçlarına yönelik sorular sorulmuştur. $\mathrm{Bu}$ kategorideki görüşmeler tercüman aracılığıyla ArapçaTürkçe/İngilizce olarak yürütülmüş, ses kaydı alınmamış ve cevaplar eş zamanlı olarak saha çalışmasında görev alan araştırmacı ve/veya bursiyer tarafından not edilmiştir. Ayrıca, STK'lar aracılığıyla bu kadınlara ulaşılmış fakat görüşmecilerin daha açık olabilecekleri bir ortam yaratmak amacıyla STK temsilcilerinin görüşmelerde yer almamaları istenmiştir. Adana'da 2, İstanbul'da 1 ve Gaziantep'te 1 görüşme kadınların Türkmen olmaları sebebiyle Türkçe olarak gerçekleştirilmiştir. Kurumlardan destek alan kadınlarla gerçekleştirilen görüşmeler 30-80 dakika arasında sürmüştür. Görüşülenlere kimlik bilgileri sorulmamış ve isimlerinin çalışmada kullanılmayacağı belirtilmiştir. Bu doğrultuda, makalede anlatılarına değinilen katılımcılar gerçek isimleriyle değil takma isimleriyle anılmaktadır.

Tablo: 1

Araştırma Örneklemi

\begin{tabular}{|c|c|c|c|c|c|c|}
\hline İl & STK & $\begin{array}{c}\text { STK } \\
\text { Çalışanı } \\
\text { Katılımcı }\end{array}$ & $\begin{array}{c}\text { STK Destek } \\
\text { Alan Mülteci } \\
\text { Katılımc1 }\end{array}$ & $\begin{array}{l}\text { STK Çalışanlarıyla } \\
\text { Toplam Görüşme (Il) }\end{array}$ & $\begin{array}{l}\text { Mültecilerle Toplam } \\
\text { Görüşme (Il) }\end{array}$ & Toplam \\
\hline \multirow{2}{*}{ Adana } & SGDD & 5 & 7 & \multirow{2}{*}{8} & \multirow{2}{*}{13} & \multirow{2}{*}{21} \\
\hline & CANSUYU & 3 & 6 & & & \\
\hline \multirow{3}{*}{ İstanbul } & HAYATA DESTEK & 4 & 6 & \multirow{3}{*}{13} & \multirow{3}{*}{17} & \multirow{3}{*}{30} \\
\hline & KADAV & 4 & 6 & & & \\
\hline & MAZLUMDER & 5 & 5 & & & \\
\hline \multirow{3}{*}{ Konya } & SGDD & 4 & 6 & \multirow{3}{*}{12} & \multirow{3}{*}{18} & \multirow{3}{*}{30} \\
\hline & DOSTELI & 4 & 6 & & & \\
\hline & ELBIR & 4 & 6 & & & \\
\hline \multirow{3}{*}{ Gaziantep } & SGDD & 5 & 6 & \multirow{3}{*}{14} & \multirow{3}{*}{18} & \multirow{3}{*}{32} \\
\hline & BELKIS & 4 & 6 & & & \\
\hline & KAMER & 5 & 6 & & & \\
\hline \multirow{3}{*}{ İzmir } & MUDEM & 6 & 5 & \multirow{3}{*}{14} & \multirow{3}{*}{17} & \multirow{3}{*}{31} \\
\hline & Suriyeli Mültecilerle Dayanıșma Derneği (SMDD) & 4 & 6 & & & \\
\hline & İzmir Müzisyenler Derneği (İMD) & 4 & 6 & & & \\
\hline \multicolumn{2}{|r|}{ 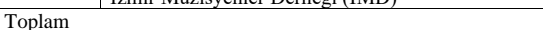 } & & & 61 & 83 & 144 \\
\hline
\end{tabular}

\section{Katılımcı Demografik Profilleri}

\subsection{STK Temsilcisi Katılımcıların Profili}

Derinlemesine görüşme yapılan kişilerin seçiminde mümkün olduğunca cinsiyet dağımı, yaş, medeni durum ve eğitim durumu ve STK'da alınan görev dağılımı gözetilmiştir.

Bu çalışma çerçevesinde görüşülen STK çalışan/gönüllülerinin \%27,6's1 (16 kişi) erkek, \%72,4’ü (42 kişi) kadındır. Mülteci kadınlara yönelik derneklerde yoğun olarak kadınların gönüllü/çalışan olarak yer aldığı düşünüldüğünde örnekleme dahil edilen STK temsilcilerinin de çoğunlukla kadın olması beklenilir bir durumdur. 
Tablo: 2

STK Temsilcisi Katılımcılar Yaş Dağılımı

\begin{tabular}{|c|c|c|}
\hline & KATILIMCI SAYISI & YÜZDE \\
\hline YAȘ GRUBU & 5 & $\% 8,1$ \\
\hline $18-24$ & 20 & $\% 32,7$ \\
\hline $25-30$ & 12 & $\% 13,6$ \\
\hline $31-36$ & 8 & $\% 13,1$ \\
\hline $46-45$ & 8 & $\% 6,6$ \\
\hline 55 ÜSTÜ & 4 & $\% 6,5$ \\
\hline KAYIP VERI & 4 & $\% 100$ \\
\hline TOPLAM & 61 & \\
\hline
\end{tabular}

Görüşme yapılan kişilerin medyan yaşı 32 ve yaş ortalaması 35'tir. Tablo 2 katılımcıların yaş gruplarına dağılımını göstermektedir. Sivil toplum alanında genellikle gönüllü ve profesyonel çalışma biçiminin genç kuşakta daha yaygın olduğu düşünüldüğünde, katılımcıların büyük oranının da 36 yaş ve altı kişilerden oluşması geneli yansitmaktadir.

Sivil toplum kuruluşlarından görüşme yapılan kişilerin önemli bir kısmının yüksek öğrenim gördüğü görülmektedir. Bu kategoride görüşme yapılan 61 kişinin 32 tanesi üniversite mezunu, 11 tanesi yüksek lisans mezunu ve 5 tanesi de yüksek lisans yapmakta olup toplam 48 tanesi üniversite ve üstü eğitim seviyesine sahiptir (Şekil 1).

Şekil: 1

\section{Temsilcisi Katılımcılar Eğitim Düzeyi}
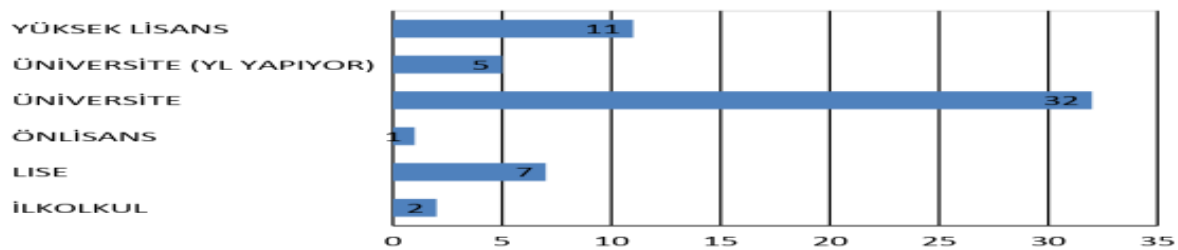

Şekil 2 katılımcıların STK'larda aldıkları görevleri özetlemektedir. STK'ların bütün faaliyetlerine dair kapsamlı bilgilerin edinilebilmesi için her STK'dan içlerinde başkan, merkez sorumlusu ve kurucuların da olduğu yöneticilere ulaşılmaya çalışılmıştır. Şekilde de özetlendiği gibi katılımcılar arasında frekansı en yüksek olan görev biçimi yöneticilerdir. 
Şekil: 2

STK Temsilcisi Katılımcılar Görev Dağılımı
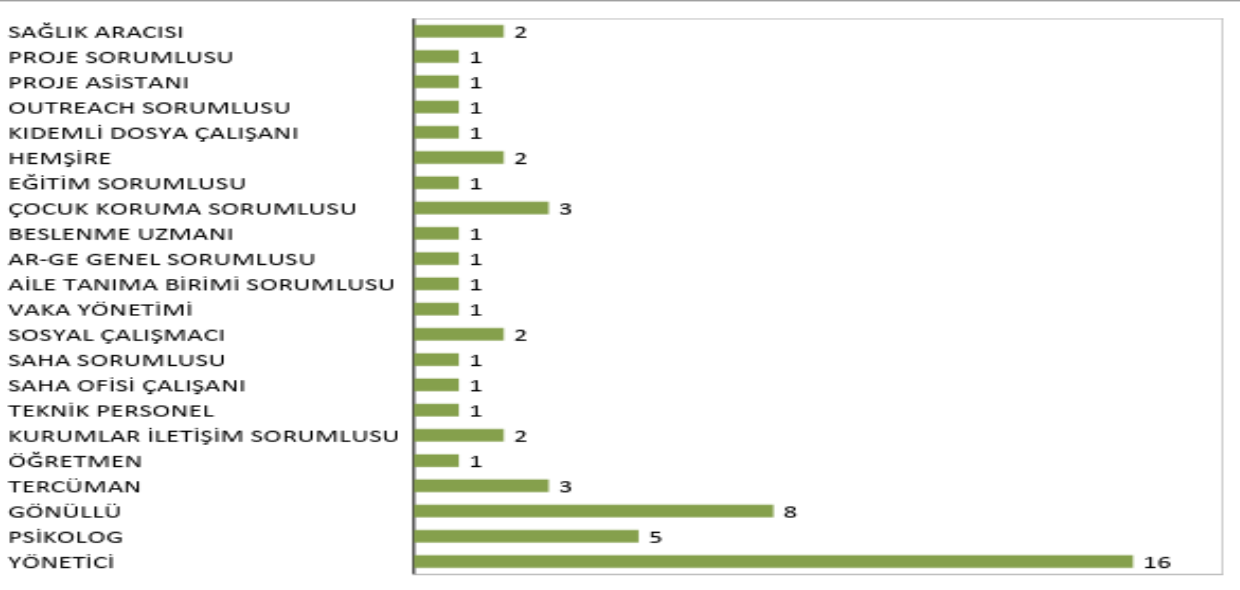

\subsection{Hizmet Alanlar Katılıme Demografik Bilgiler}

STK'lardan hizmet alan mülteciler kategorisinde araştırma sorusu gereği yalnızca kadınlarla görüşmeler yapılmıştır. Görüşme yapılan kadınların yaş ortalaması 35, medyan yaşı 34'tür ve yaş gruplarına dağılımı Tablo 3'te gösterilmektedir.

Tablo: 3

Hizmet Alan Katılımcılar Yaş Dağılımı

\begin{tabular}{|c|c|c|}
\hline YAŞ GRUPLARI & FREKANS & $\%$ \\
\hline $15-24$ & 6 & 7,2 \\
\hline $25-30$ & 22 & 26,5 \\
\hline $31-36$ & 24 & 28,9 \\
\hline $37-45$ & 22 & 26,5 \\
\hline $46-55$ & 6 & 7,2 \\
\hline 55 ÜSTÜ & 3 & 3,6 \\
\hline TOPLAM & 83 & 100 \\
\hline
\end{tabular}

Mülteci kadınların medeni durumları kendi ifade ettikleri şekilde sınıflanmıştır. Görüşme yapılanların en büyük çoğunluğu (55 kişi) evli olduğunu belirtmiş, kocası ölenler ise ikinci büyük kategoriyi oluşturmaktadır (Şekil 3). Tablo 4 bu kategorideki kadınların çocuk sayılarını özetlemektedir. Ortalama çocuk sayısı 3,5 olmakla birlikte evlenmiş kadınlardan sadece 6 tanesinin çocuğu bulunmamaktadır. 
Şekil: 3

Hizmet Alan Katılımcılar Medeni Durum Dağılımı
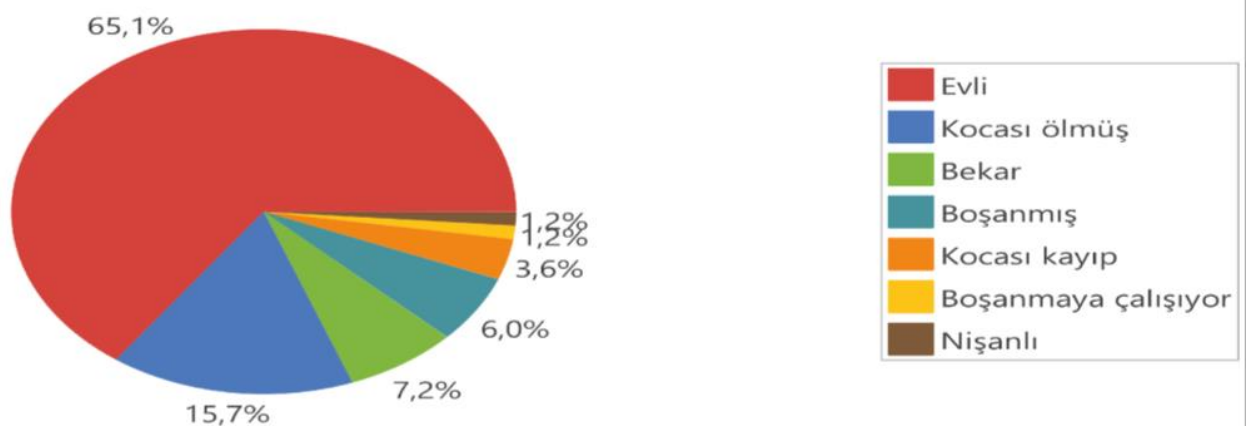

Tablo: 4

Hizmet Alan Katılımcılar Çocuk Sayısı

\begin{tabular}{|c|c|c|}
\hline Çocuk Sayısı & Frekans & Yüzde \\
\hline $\mathbf{0}$ & 13 & 15,66 \\
\hline $\mathbf{1}$ & 2 & 2,41 \\
\hline $\mathbf{2}$ & 9 & 22,84 \\
\hline $\mathbf{3}$ & 19 & 25,30 \\
\hline $\mathbf{5}$ & 21 & 8,43 \\
\hline $\mathbf{6}$ & 7 & 7,23 \\
\hline $\mathbf{7}$ & 6 & 2,41 \\
\hline $\mathbf{8}$ & 2 & 2,41 \\
\hline TOPLAM & 2 & 2,41 \\
\hline
\end{tabular}

Görüşme yapılan kadınlar çoğunlukla eşleriyle aynı şehirde yaşamaktadır, ancak kadınların \%20'si ya eşlerinin kayıp olması nedeniyle ya da başka bir ülke/şehirde olması nedeniyle ayrı yerlerde ikamet etmektedir (Şekil 4).

Şekil: 4

Hizmet Alan Katılımcılar Eşinin Yaşadığı Yer

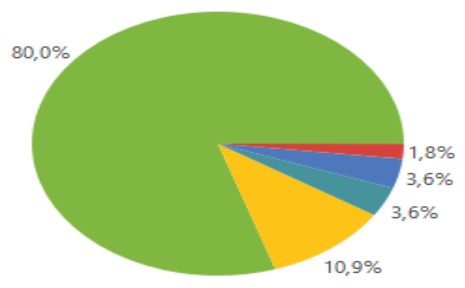




\section{Suriyeli Mülteci Kadınların Türkiye'de Yaşadığı Zorluklar, İhtiyaçlar ve Beklentiler}

Örnekleme dahil olan ve çeşitlilik gösteren Suriyeli kadınlara Türkiye'de en çok zorlandıkları konular, sorunlar ve ihtiyaçlarına yönelik bir dizi soru yöneltilmiştir. Bu sorulara verilen cevaplar farklılaşsa da Suriyeli mülteci kadınların Türkiye'de yaşadıkları zorluklar dil bilmeme, ekonomik zorluklar, ayrımcılık, yasal zorluklar, sağlık hizmetlerine erişim, eğitime erişim ve yabancı olmaya ilişkin zorluklar başlıkları altında toplanabilir (Şekil 5).

\subsection{Zorluklar: "Dil bilsem kimseye muhtaç olmam"}

Şekil: 5

Türkiye'de Yaşanan Zorluklar

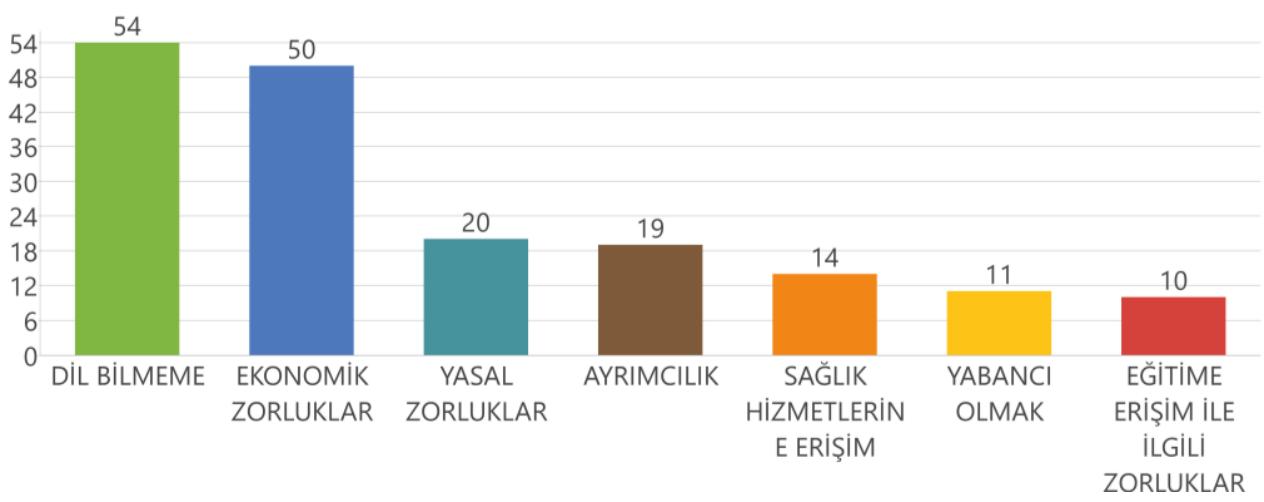

Suriyeli mülteci kadınların Türkiye'de yaşadıkları en sık dile getirdikleri sorunun dil bilmemek olduğu tespit edilmiştir (Şekil 5). Dil bilmemek, tahmin edileceği üzere, yeni gelinen ülkede birçok alanda kadınların karşılaştığı sorunları daha da keskinleştirmekte ve hayatlarını zorlaştırmaktadır. Örneğin, dil bilmemek kadınları diğer insanlara bağımlı bir biçimde hayatlarını sürdürmelerine neden olmaktadır. Örneğin çocuklarının okulunda dil kursu olan ama çocuklara bakacak kimse olmadığı için gidemeyen Cavidan "Dil bilsem kimseye muhtaç olmam" (35, Kocası Ölmüş, Konya) ifadesini kullanmıştır. Gelinen ülkedeki dilin konuşulamaması elbette sadece Suriyeli mülteci kadınlara özgü bir sorun olmanın çok ötesindedir, zira farklı ülkelerde gerçekleştirilen çalışmalar da dil becerisi eksikliklerinin göçmen kadınları sağlığa erişimden diğer kamu hizmetlerinden yararlanmaya ve iş piyasasında konumlanmaya kadar toplumsal hayatın pek çok alanında dezavantajlı kıldığını göstermektedir (Syed \& Murray 2009). Türkiye'deki Suriyeli kadınların da Türkçe dil becerisi konusundaki eksiklikleri kuşkusuz onları başkalarına bağımlı hale getiren ve zorluk çektikleri en önemli dinamiklerin başında gelmektedir. Örneğin İstanbul'da iki çocuk ve eşiyle yaşayan Perihan, büyük oğlunun Türkçe bildiğini ancak doktora gidebileceği 
zamanlar ile okul saati denk geldiği için oğlunun kendiyle gelemediğini belirtmiş ve dil konusundaki sıkıntılarını şu şekilde anlatmıştır.

Türkçe konuşamamak. Dilden kaynaklı sorunlar yaşıyoruz. Doktora giderken tercüman gerekiyor mesela. Kocamın dişi için doktora gittik, dişi ile ilgili sorunu anlamak, randevu saatinin ne zaman olduğunu bilmek hep sorun. Türkçe okumayı bilmiyoruz çünkü. Sırf bu yüzden ve doktor da randevu saatini yazmadığ gitmek zorunda kaldık, 4 aydır dişini tedavi ettirmeye çalışıyoruz. Doktorlar "okuyamiyorsan Suriyeliysen tercüman getir" diyorlar. (Perihan, 33, evli, İstanbul)

Birebir görüşme yapılan kadınların önemli bir kesimi kurumsal olarak tercüme hizmetinin sağlanmadığı durumlarda, dil biliyorlarsa çocuklarından; eğer çocuklarından destek alamıyorlarsa komşu/tanıdıklarından kişisel ilişkileri üzerinden tercüme yardımı aldıklarını aktarmışlardır. Bunun yanı sıra özellikle sağlık hizmetlerinden yararlanırken ücretli tercüman tuttuklarından da bahsetmektedirler.

Doktorlar iyi davranıyorlar ama tercüman yok, o yüzden tercüman tutuyoruz parasıyla. Bazen tercümansız gidiyoruz hastaneye ama o zaman hiçbir şey anlamadan geri dönüyoruz. Hastanede tercüman var ama kalabalık olduğu için sıra hiç gelmiyor. 100 tercüman olması lazım herkese bakabilmesi için. (Senem, 40, evli, Konya)

Ekonomik zorluklar ise Suriyeli mülteci kadınların dile getirdikleri en yaygın ikinci büyük sorun olarak görüşmelerde ön plana çıkmaktadır. Katılımcıların anlatıları, ekonomik temelli sıkıntıları çok çeşitli biçimlerde ve birden fazla çeşidi eş zamanlı olarak deneyimlediklerini ortaya koymaktadır. Görüşme yapılan kadınların bu konuda belirttikleri noktalar temel olarak Türkiye'deki temel masrafların (kira, faturalar, gıda vb.) karşılanamamasıyla ilgili sorunlar ve iş piyasasıyla ilgili sorunlar olmak üzere iki ana başlıkta tartışılabilir.

Bu noktada araştırmaya katılanların ekonomik durumlarını anlamaya yönelik sorulan sorulara verdikleri cevaplara bakmakta fayda bulunmaktadır. Mülteci kadınların ekonomik durumlarına dair kişisel kazançları, eşlerinin kazançları ve kendilerinin ülkelerindeki ve Türkiye'deki iş durumları sorulmuştur. Görüşme yapılan 83 kişiden 56'sı Suriye'deyken çalışmadığını söylemiştir. Çalıştığını belirten kişilerin meslekleri Şekil 7'de gösterilmiştir. 
Şekil: 6

Hizmet Alan Katılımeıların Suriye'deki Çalışma Durumu

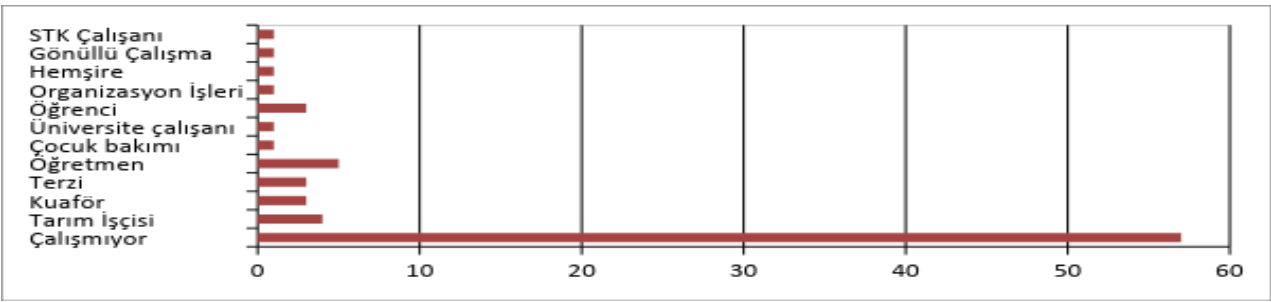

Türkiye'de çalışmadığını söyleyen katılımcı sayısı ise 60'tır. Çalıştığını söyleyen kadınların önemli bir kısmının ise parça başı, temizlik, ütü gibi işler yaparak evde çalıştı̆̆ görünmektedir (Şekil 8).

Şekil: 7

Hizmet Alan Katılımcılar Türkiye'deki Çalışma Durumu

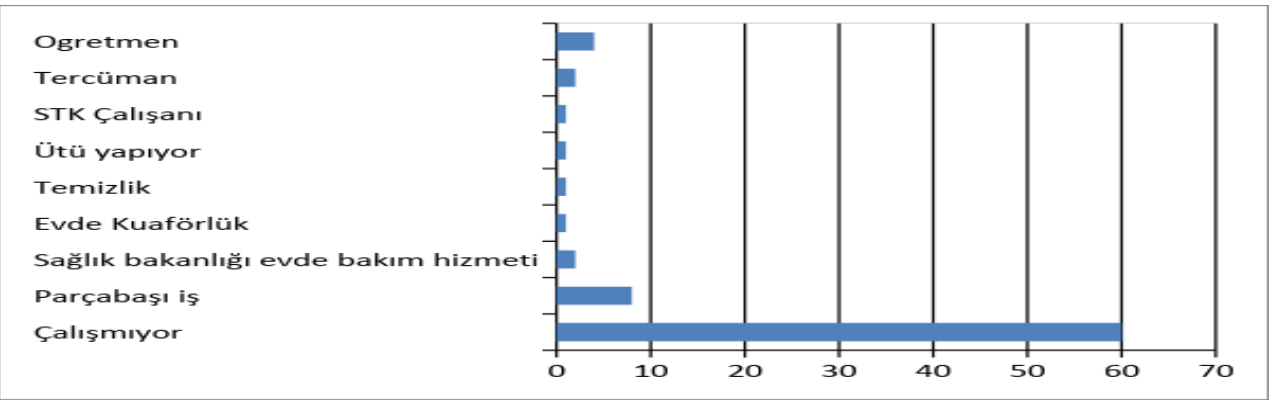

Kadınların çoğunluğunun çalışmadığı için kişisel kazançları yoktur. Kişisel kazançları olan kadınlar ise, bu soruya yanıt vermekte zorluk çekmişlerdir. Zira çoğunlukla parça başı işlerde çalışııklarını, iş gelme durumuna göre ücretlendirildiklerini belirtmişlerdir. Bu soruya yanıt veren 6 kişi aylık kişisel gelirinin 1000 TL'nin altında olduğu, 10 kişi ise aylık kişisel gelirinin 1000 TL'nin üzerinde olduğunu ifade etmiştir.

Mülteci kadınların kendi işlerinin yanı sıra ekonomik durumlarının önemli bir göstereni olarak eşlerinin iş durumu da sorulmuş ve verilen cevaplar Şekil 9'da özetlenmiştir. 14 kadın eşinin herhangi bir işte çalışmadığını belirtmiştir. Çalışan eşlerin işlerine bakıldığında ise, neredeyse hepsinin kol gücüne dayalı işler olduğu ve çoğunun nitelik gerektirmediği görülebilmektedir. 
Şekil: 8

Hizmet Alan Katılımcıların Eşlerinin Çalışma Durumu

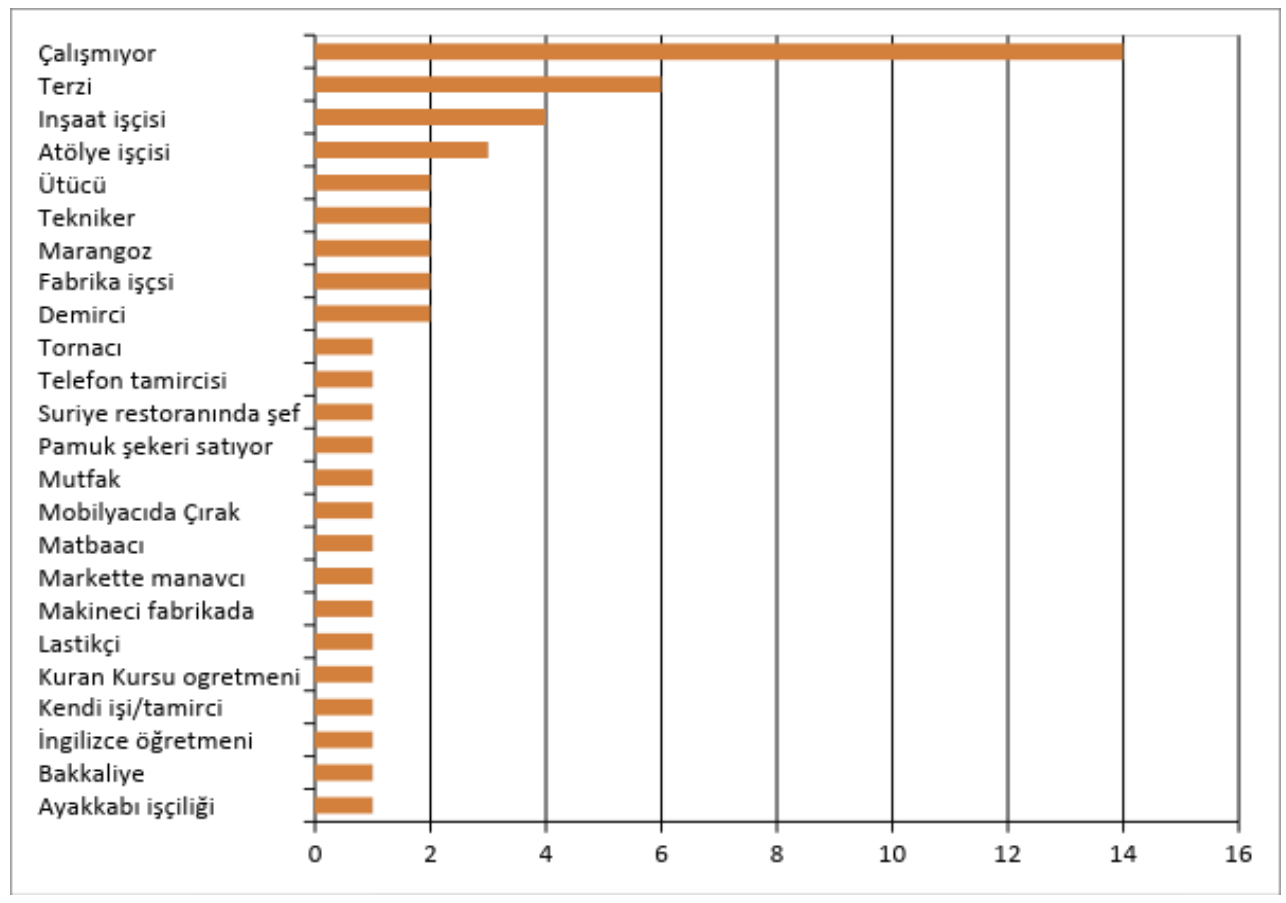

Görüş̧e yapılan mülteci kadınlara aynı zamanda eşlerinin aylık kazancı sorulmuştur. Kadınların önemli bir kısmı eşi sıklıkla iş değiştirdiği, genellikle geçici ve güvencesiz işlerde çalıştıkları için bu soruya da kesin olarak cevap vermekte zorlanmıştır. 12 kadın eşinin kazancının olmadığını söylemiştir. Eşinin kazancı olarak en yüksek belirten miktar 2000 TL olmakla birlikte sadece 4 kişi eşinin 2000 TL kazandığını belirtmiştir.

Hizmet alan katılımcılara aynı zamanda hanede beraber yaşadıkları çalışan çocuklarının gelirleri sorulmuştur. Hanedeki her kişinin kazancı hesaplandığında ise hanelerin ortalama gelirlerinin 1630 TL olduğu görülmüsstür. Şekil 10 ise, hane gelirlerinin dağılımını göstermektedir. Şekilde veriler göz önünde bulundurulduğunda ise katılımcıların \%71'inin 2000 TL ve altı hane gelirine sahip olduğu görülmektedir. Hane gelirinin görece yüksek olduğu hanelerde ise kişilerin aylık gelirinin yüksekliğinden çok birden fazla çalışan olduğu gözlemlenmiştir. 
Şekil: 9

Hizmet Alan Katılımcılar Aylık Hane Geliri

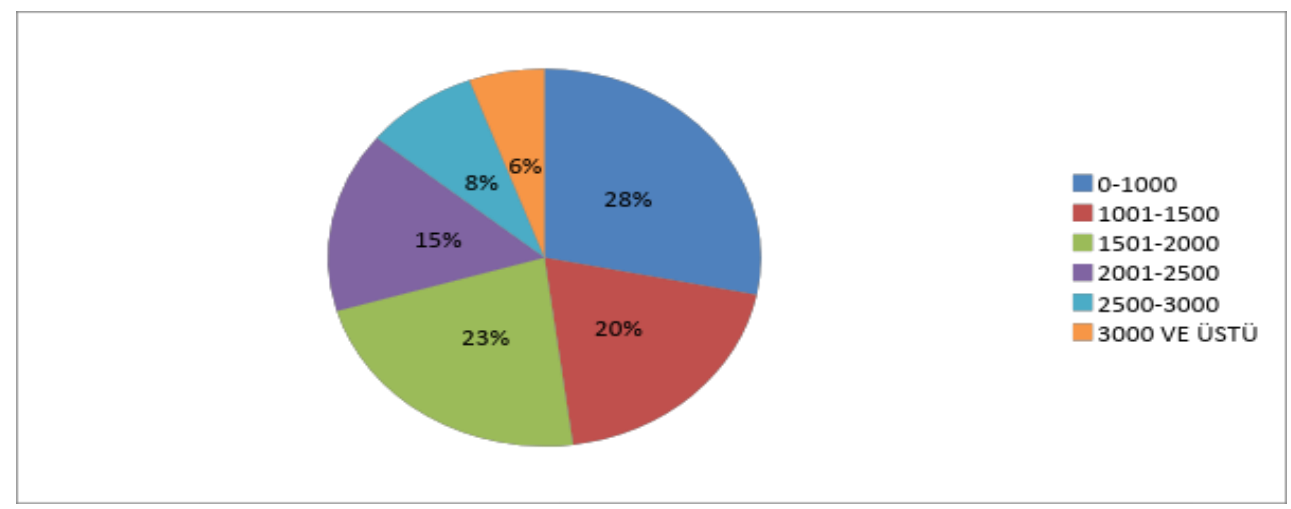

Görüşme yapılan kadınlara herhangi bir ya da daha fazla kurumdan nakdi yardım alıp almadığı sorulmuş, 58 kadın bir kurumdan nakdi yardım aldığını belirtmiştir. Alınan toplam yardım miktarı $40 \mathrm{TL}$ ile $1450 \mathrm{TL}$ arasında değişmekte olup, ortalama aylık yardım miktarının 450 TL olduğu tespit edilmiştir. Yardımların büyük çoğunluğunun Kızılay Kart ile gerçekleştirildiği belirtilmiştir. Şekil 10 hanelerin aldığı yardım miktarının dağılımını göstermektedir. Bu şekilde de açık olarak görüldüğü üzere yardım alanların büyük çoğunluğu alınan toplam yardım miktarını 500-750 TL arasında olduğunu belirtmektedir ve bu miktarın temel girdisini Kızılar Kart oluşturmaktadır.

Mülteci kadınlara hem ülkelerindeki hem Türkiye'deki kazançlarının geçimlerine yetip yetmediği de sorulmuştur. Kadınların büyük çoğunluğu Suriye'deyken geçimlerine yetecek kadar kazanırken, Türkiye'de durumun böyle olmadığını belirtmişlerdir (Şekil 11 ve Şekil 12). Kadınlar bu durumu, ülkelerindeki savaşın ekonomik durumlarını çok ciddi etkilemesi ve göç sonrasında her şeye sıfırdan başlamak zorunda kalmalarıyla ve aynı zamanda Türkiye'deki geçim şartlarının Suriye'den daha ağır olduğu için eskisi gibi hanede tek çalışan bulunmasının geçinmeye yetmemesi ile açıklamışlardır:

"Tüm gün ve gece çalışıyoruz ama yine de nefes alacak kadar bile rahatlayamadık. Kocamın, iş durumu ve istikrarsız hayat yüzünden bir sürü sorun yaşıyoruz. Hayatlarımızı en çok zorlaştıran şey de kaçakçı borçları olması. Faturaları (300 TL) ve kirayı (500 TL) ödemekte zorlanıyoruz. Çocukların masrafları var, kaçakçı borçlarını ödeyebilsek biraz daha rahatlayabiliriz.” (Perihan, 33, Evli, İstanbul)

"Burada çok zor, dil yaşamak her şey. Çalışan tek çocuğum var". Kira: 450 TL, faturalar: 150 TL civarı. (Feride, 45, Kocası Ölmüss, Gaziantep)

"Maalesef yetmiyor. Kira ve faturalar toplam: 1050 TL civarı tutuyor. Yazın çocukların çalışıp kazandığını kışa da pay ediyoruz, öyle geçinmeye çalışıyoruz. Yazın daha rahat yaşayabiliyoruz.” (Sare, 40, Boşanmış, İstanbul) 


\section{Sekil: 10}

\section{Hizmet Alan Katılımcılar Türkiye’deki Gelir Yeterliliği}

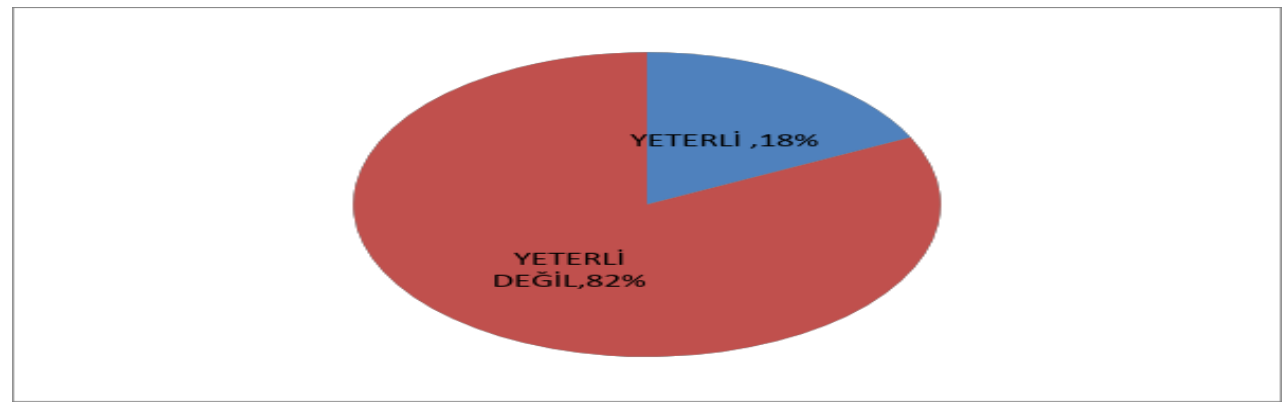

Şekil: 11

Hizmet Alan Katılımcılar Suriye'deki Gelirin Yeterliliği

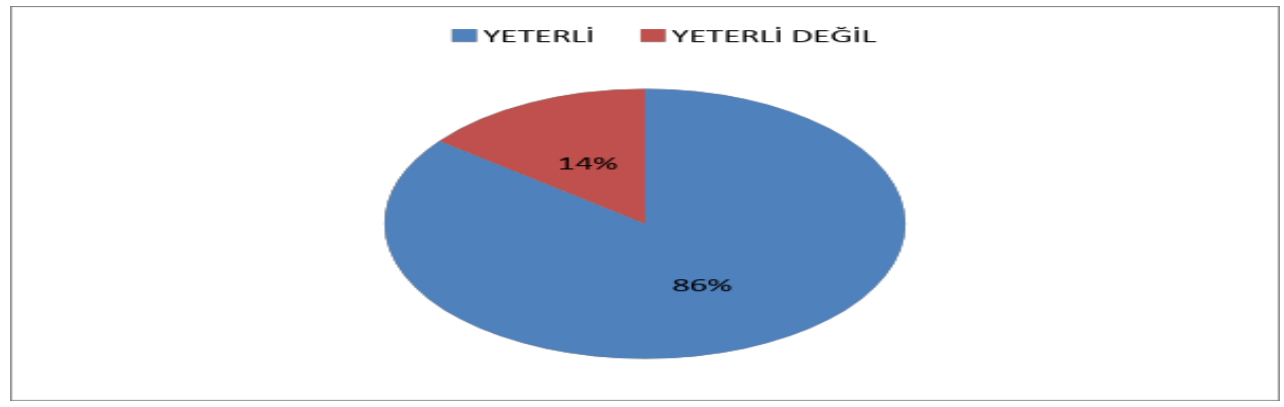

Hizmet alan grubunda çalışmaya katılanların ekonomik durumlarına ilişkin anlatılardan çıkan göstergeler çerçevesinde kadınların en temel ihtiyaç alanı olarak ekonomik ihtiyaçları belirtmesinin şaşırtıcı olmadığını söylemek mümkündür. Zira bu göstergeler kadınların genel olarak düzenli gelirin olmadığı, var olan gelirin hanenin geçimi için yeterli olmadığı ve mevcut gelirin bile kazanılması için zor, düzensiz işlerde haneden birden fazla kişinin çalıştığını göstermektedir.

Kira başta olmak üzere temel yaşam giderlerinin Suriyeli kadınlar için en önemli ekonomik sorunların başında geldiği ve saha çalışmasına dahil edilen kadınların büyük bir tedirginlik ve kaygı ile bu sorunlardan bahsettiği gözlemlenmiştir. Antep’te görüşülen Şermin'in eşi Suriye'de kalmıştır ve kendisi temizlikçilik yaparak ve aldığ 1 desteklerle 6 çocuğu ile birlikte yaşamaktadır. Burada yaşarken karşılaştığı en büyük zorluğun ne olduğu sorusuna verdiği "Faturalar... Su faturası kaç lira gelecek diye yüreğim küt küt atıyor" cevabı bu konuda yaşadığ 1 tedirginliği ortaya çıkartmaktadır. 75 yaşındaki Sultan ise Gaziantep'te tek başına yaşamakta ve terzilik -çocuk bakımı yaparak geçinmektedir. O ise bu soruya şu şekilde yanıt vermiştir: "Ev kirası...Sade ekmek yesem yeter". 
Özgür-Keysan, A. \& B. Şentürk (2021), "Sorunlar ve Beklentilerin Algılanmasında

Kadın Mülteciler ve Sivil Toplum Kuruluşları”, Sosyoekonomi, 29(48), 343-376.

İş piyasasına ilişkin zorluklar ise temel olarak kadınların eşlerinin işleriyle ilgili anlatılarla şekillenmekte ve bu anlatılar eşlerinin iş bulamaması, uzun saatler çalışması, ücretlerini alamaması, iş bulmasının zorluğunu içermektedir. Eşinin uzun saatler çalışmasından yakınan bir Suriyeli kadın görüşmeci Pazar günü hariç her gün kocasının çalışmasından dertlenmiş, durumu şöyle ifade etmiştir: 'Sabah 8:30'dan akşam 8'e kadar çalışıyor. Suriye'de de uzun çalışıyordu ama en azından öğlen görüşüyorduk. Suriye'deki kendi işiydi kocamın" (Ayşe, 32, Evli, İstanbul).

Suriyeli mülteci kadınlar iş olanağının olmamasını hem kendileri hem de eş ve çocukları adına dile getirmiş ve iş olması durumunda dahi düzenli olmamasını ekonomik zorluklar altında belirtmişlerdir. Ekonomik zorlukların iş piyasasıyla ilgili ayağında ikincil olarak kadınların kendilerinin iş piyasasındaki dezavantajlı durumdan bahsettiği söylenebilir. Kadınlar bakım emeği, kültürel faktörler gibi hanenin çekici güçlerinin etkisiyle (Walby, 2016), ya da savaşta zarar gördüğü için çalışamama gibi diğer faktörlerin etkisiyle iş gücü piyasasına katılamadıklarını, haneye dair faktörlerin ya da diğer özel faktörlerin iş gücü piyasasına katılmalarına engel olmadığı durumlar söz konusu olduğunda bile, piyasadaki dezavantajlı konum ekonomik bir zorluk olarak deneyimlenmektedir. $\mathrm{Bu}$ noktada makro değişimler ve krizlerin toplumların farklı kesimlerini aynı şekilde etkilemediği, sınıfsal, ulusal ve kimliksel kesenler eşliğinde farklı toplumsal kesimlerin değişimlere eklemlendiğinden (Yılgör, 2019) bahsetmekte fayda vardır. Zira özellikle alan araştırmalarına dayalı çalışmalar, hayatın pek çok alanında olduğu gibi, göç, göçmen olmak, gibi toplumsal durumlarda da kadınlar ve erkeklerin deneyimlerinin farklılaştığını ve kadınların deneyimlerinin göz ardı edilmeye daha meyilli olunduğunu ortaya koymaktadır (Şentürk, 2015; Pratt \& Yeoh, 2003; Ballarion \& Panichella, 2018; Raghuram, 2008). Suriyeli kadınların iş piyasasındaki dezavantajlı konumuna dair bulgularımıza geri dönersek, iş piyasasında hali hazırda dezavantajlı bir konum olan göçmenlik, patriarkal kültürel yapının toplumsal organizasyonu etkileme biçimiyle bir araya gelerek kadın göçmenleri daha da olumsuz etkilediğini söylemek mümkün olabilir. Kaldı ki göçmen kadınların farklı ülke iş piyasalarında kendileri gibi göçmen olan erkeklerden farklı şekillerde ve daha dezavantajlı şekillerde iş piyasalarına eklemlendiğini gösteren çalışmaların (Fleury, 2016) mevcudiyeti patriarkanın işleyişini özetlemektedir.

Çocukların çalışmak zorunda kalması ve onların da piyasadaki güvencesiz koşullarla yüz yüze olması ekonomik sıkıntılar bağlamında sıkça değinilen diğer bir konu olarak karşılaşılmaktadır. Kocası kayıp olan Kadriye'nin dört çocuğundan 13 ve 14 yaşlarında olan en büyük ikisinin çalışması karşılığında aldıkları ücret evin temel geçim kaynağını oluşturmaktadır. Kadriye bu durumu ciddi bir sorun olarak tanımlamış ve bu durumu "Onlar (çocuklar) küçük çalışmak yerine okulda olmaları lazım” diye ifade etmiştir.

Aynı zamanda çocuklarına çok iş verilmesi ve düşük ücretle çalıştırılmasına ve dahası çocuklarının patron şiddetine maruz kalmasına çok üzülen Tülin, çocukların okula gitmesi durumunda eve bakacak kimsenin olmayacağına ve aç kalacaklarını söylemiştir. Çocuklarına çok iş verdiklerini 7 makine çalıştıklarını ve düşük ücret verdiklerini söyleyen Tülin, işverenlerin çocuk ve küçük oldukları için kısa çalıştırılmalarını istemiş ve oğlunun 
bir kere "keşke gelmeseydik, Suriye'de ölseydik daha iyiydi” dediğini eklemiştir (Tülin, 41, Evli, Gaziantep). Tülin'in oğlu patronun kendisini sürekli dövdüğünü, mafya olduğu için patronunu şikâyet etmekten korktuğunun altını çizmiştir.

Suriyeli mülteci kadınların yaşadıkları temel sıkıntılar konusunda medeni durumlarının da etkili olduğu gözlemlenmiştir. Her kategorideki kadınlarda ekonomik zorluklar ve dil bilmemenin getirdiği zorluklar birbirini takip eden iki büyük sorun olarak gözlemlense de evli olmayan kadınlar neredeyse yalnızca bu iki sorundan en temel sorunları olarak bahsederken evli olan ve özellikle çocuğu da çalışan kadınlar dil bilmeme sorunundan ve ekonomik sorunlardan daha az bahsederek yasal sorunlar, sağlığa erişim gibi diğer sorunlardan da bahsetmişlerdir. Bu durumda, evin temel geçim kaynağını sağlamak konusunda hane üyelerinin desteğini alamayan kadınların en büyük sıkıntılarının ekonomik zorluklar olması ve iş hayatına katılımda ve diğer toplumsal ilişkileri sürdürmekte kendilerine engel olan dil bilmeme durumunu yine daha büyük bir sıkıntı olarak yaşamaları beklenmedik bir durum değildir.

Ekonomik sıkıntılar ve dil bilmemenin yanı sıra ayrımcılık, yasal zorluklar ve sağlık ve eğitim gibi haklardan yararlanamama gibi ekonomik sıkıntılar ve dil bilmeme durumu ile yakından ilişkili bir takım sıkıntılardan da bahsedilmiştir. Figen ve Tuğba sağlık hizmetlerine erişirken karşılaştıkları ayrımcılıklardan şu şekilde bahsetmişlerdir. Örneğin Figen (28, Kocası Ölmüş, Konya) "hastaneye gittiğimizde doktor kızıma çok iyi davranmıyor, başka doktor olmadığı için de o doktora mecbur kalıyoruz. Doktor ciddiye almıyor bizi" demiştir. Tuğba ise hastanede yaşadığı kötü tecrübeyi aşağıdaki gibi dile getirmiştir.

Hamileyken bir kere hastaneye gittim, doktor ve hemşire Arap olduğum için bir şeyin yok deyip ne ağrı kesici ne ilaç vermeden yolladı. Ertesi gün gittim tekrar hemen sezeryana aldılar, Türkiye’de doğum yapmak en kötü şeydi, bizi hiç önemsemiyorlar. Türkmen komşum hastanede bir kere yardım etti, yardım etmezseniz polisi ararım dedi hastane güvenliğine. Arap'ız diye bizi sevmiyorlar, polis korkusuyla işlerini yapıyorlar. (Tuğba, 28, Evli, İzmir)

Türkiye'ye çocuğunun sağlığıyla ilgili bir izinle geldiğini ileten ve eşinin geçişine izin verilmediğini belirten Gül'ün aktardıkları ise, dil bilmeme durumunun sağlık hizmetlerine erişimiyle ilişkisini ve kadın mülteci olarak yaşamanın anlamına dair farklı temaları eş zamanlı olarak gösterir niteliktedir:

Devamlı hastanede olduğum için halkla çok haşır neşir değilim. Bir şey sormak istediğimde dil bilmediğim için sağlık personelinin hemen asabileşip tersliyor. Kimsesiz olduğumu anladıkları için hastanedeki bazı erkekle bana "seks" için para teklif etti. (Gül, 30, Eşi Suriye'de, Adana)

Şehirlere göre Suriyeli kadınların Türkiye'de karşılaştıkları zorlukları analiz ettiğimizde ise, ayrımcılığın bir sorun olarak en çok İstanbul'da dile getirildiğini, dil 
bilmemenin ise en çok Konya'da bir sorun olarak karşımıza çıktığını görüyoruz. Ayrıca, illeri kendi içinde değerlendirdiğimizde İzmir, Konya Gaziantep ve İstanbul'da kadınlar en büyük sorunu dil bilmemek olarak dile getirirken, Adana'da bu durum ekonomik problemler karşımıza çıkmaktadır.

\section{2. İhtiyaçlar ve STK'lardan Beklentiler: Halı, İki Yastık ve Buzdolabı}

Suriyeli mülteci kadınlara Türkiye'de yaşadıkları zorlukların yanı sıra ihtiyaçları ve bu ihtiyaçların giderilmesinde STK'lardan beklentilerine dair de bir dizi soru yöneltilmiştir. Yaşadıkları temel zorlukların ekonomik zorluklar ve dil bilmemeyle ilgili zorluklar olduğu tespit edilen kadınlar, Türkiye'deki temel ihtiyaç alanlarını belirtirken de deneyimledikleri zorluklarla paralel birincil olarak ekonomik ihtiyaçlardan, ikinci olarak ise eğitim ve sağlığa erişime dair ihtiyaçlardan bahsetmişlerdir (Şekil 13). Mülteci kadınlardan bir tanesi ihtiyaçlarını sorduğumuzda 2 halı, 1 yastık, kıyafet, tüp ve çamaşır makinası olarak sıralamıştır (Hayriye, 40, Kocası ölmüş, Konya).

\section{Şekil: 12 \\ Hizmet Alan Katılımcıların Türkiye'deki İhtiyaçları}

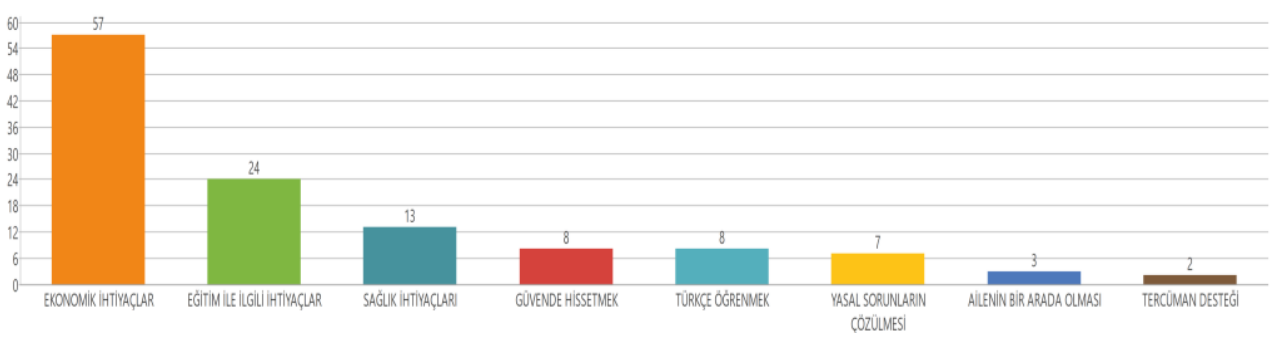

Görüşme yapılan kadınların ihtiyaçlarını açıklarken en çok vurgu yaptıkları çerçeve olan ekonomik ihtiyaçlar, beklenildiği üzere öncelikle eşler olmak üzere evdeki yetişkin erkeklerin iş bulması ve iş buldukları durumlarda ise bu işlerin güvenceli ve insan onuruna yakışır olmasıdır. Zira kadınlar Türkiye'de yaşadıkları zorlukları ve ihtiyaçlarını açıklarken sıklıkla iş piyasasında yaşanılan ayrımcılıklardan yakınmışlar ve yardımdan ziyade sabit gelirli işe olan ihtiyaçlarının altını çizmişlerdir.

4 senedir Türkiye'deyiz, artık alıştık, dil ilk başta çok zordu. Bir de kocama maaşını defalarca vermediler. Türkler Suriyelileri kandırıyor ya az maaş ya da hiç para vermiyorlar. (Lale, 36, Eşi Ölmüş, Konya)

Kadınların kendilerinin iş bulması ile ilgili ihtiyaçlarından bahsettiği durumlarda da katılımcılar iş piyasasındaki ayrımcılıklardan sıklıkla yakınmaktadır. Örneğin kocası kaybolan Nükhet göçle beraber çalışmaya başlamıştır. Suriyelilerin çalışma koşullarından bahsederken sabah 7'den akşam 8'e kadar çalışmak zorunda olduklarını ve buna rağmen düşük maaş aldıklarını belirtmiştir. Kadınların ev dışında çalışmasının yaşlı ve evde bakıma muhtaç kişilerin olup olmaması ya da var ise bu kişilerin bakımında destek olabilecek diğer 
hane bireylerinin varlığı ile yakından alakalı olduğu da gözlemlenmiştir. Bu noktada dil öğrenme ile ilgili ihtiyaçların çok önem kazandığı söylenebilir. Kaldı ki kadınların önemli bir kısmı Türkiye'deki sıkıntılarını açıklarken en çok ekonomik ihtiyaçlara vurgu yapsalar da çalışabilecek durumda olan 30'lu yaşlarda, evinde bakıma muhtaç kişinin olmadığı ya da bu kişilerin bakımında destek sunabilecek kişilerin olduğu kadınlar sıkıntılarının önemli bir kısmının dil bilmemeyle alakalı olduğunu öne sürmektedirler.

Türkçe öğrenmeye ve tercümana yönelik ihtiyaçlar ise belirtilme sıklığı açısından başlarda yer almamakla birlikte (Şekil 13) bu ihtiyaçların diğer ihtiyaçlarla iç içe geçtiği ve diğer ihtiyaçların karşılanmasında önemli bir noktayı teşkil ettiği açıklıkla söylenebilir. Zira kadınlar, bu çalışmanın diğer kısımlarında da belirtildiği üzere sağlığa erişimle ilgili sıkıntılarından bahsederken sik sik tercüman eksikliğinin ve dil bilmemenin yarattığ zorluklara değinmiş ve bu durumun sağlığa erişimlerini etkilediğini anlatmışlardır. Yine benzer bir şekilde dil becerileri ile ilgili sıkıntılar ekonomik ihtiyaçların başında gelen iş bulma durumunu doğrudan etkilemektedir. Öte yandan dil bilmeme ya da hem yetişkinlerin hem çocukların eğitime ilişkin sıkıntılarını şekillendirmektedir. Örneğin Begüm (36, Boşanmış, Gaziantep) Türkçe bilmediği için çocuklarının ödevlerine yardımıı olamadığını ve okul ile yeterince temas kuramadığını belirtirken, eğitim ile ilgili ihtiyaçlarını olduğunu belirten katılımcıların yarıya yakını kendilerinin ve çocuklarının Türkçe öğrenmeye yönelik ihtiyaçlarından bahsetmişlerdir.

İş gücü piyasasına girmenin yanı sıra dil bilmeme durumunun kadınları hastane ve okullar gibi kurumlarla ilişki kurma ve toplumsal hayata katılım konusunda sınırlandırdığ1 belirtilmiştir. Bu noktada dil bilme durumu, aslında zorluk yaşanan farklı alanları doğrudan etkileyen ve kadınların eğitim ve sağlık gibi kaynaklara erişsimini belirleyen bir dinamik olarak belirmektedir.

STK'ların sağladıkları imkanlar ve hizmetler ile mülteci kadınların ihtiyaçları, sorunları ve beklentileri arasındaki ilişkinin ortaya çıkarılmasına yönelik olarak mülteci kadınlara STK'lardan aldıkları hizmetlerden memnun olup olmadıkları ve neler bekledikleri soruları yöneltilmiştir. Mülteci kadınların büyük bir çoğunluğu hizmet aldıkları STK'dan memnun olduğunu belirtmiştir. Şekil 13'te görüldüğü gibi, bu kadınlar STK'lardan memnuniyetlerini 'güvende hissetme', 'güçlü hissetme' 'düzenlenen etkinliklerin güzel olması' ve 'çalışanların iyi olması' gibi sebeplerle açıklamaktadır. Ancak bu hizmetlerden memnun olduğunu fakat yetersizliğini vurgulayan da bir grup kadın da bulunmaktadır. 


\section{Şekil: 13 \\ Hizmet Alan Katılımcılar STK'lardan Memnuniyet Düzeyi}

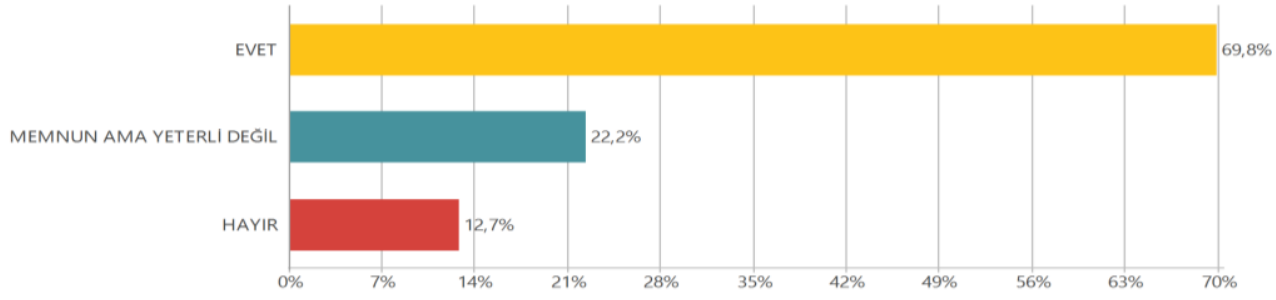

STK'lardan memnun olmadığını belirtenlerin memnuniyetsizlik sebepleri aynî yardımların kalitesini düşük bulmaları, STK'lardaki yardımların adil dağıtılmadığı, verilen hizmetlerin kendi ihtiyaçlarını karşılamadığını düşünmeleridir. Bu konuyu mülteci kadınlar şu şekilde ifade etmişlerdir:

Memnun değiliz, genel olarak [yardım] veriyoruz dediler ama hiçbir şey görmüyoruz. Kızılay iyi bir kart ama öğrenciler için verdikleri çok yetersiz. 35 TL 1 haftada biter. (Meliha, 16, Bekâr, Konya)

Kurumlar yeteri kadar organize değil ve bu yüzden çok uzun kuyruklar var [...] Tanıdıklara veriyorlar gerçekten ihtiyacı olanlara değil. (Ayda, 30, Evli, İzmir)

STK'lardan memnun olduklarını ancak yine de hizmetleri yeterli bulmadıklarını belirten mülteciler ise genel olarak aldıkları yardımların geçimlerine yetmediğinden, kısa vadeli olduğundan, tercüman sayısının yeterli olmadığından bahsetmişlerdir:

[Eskiden] Memnundum. Hastanede bir tercüman oluyor, yetmiyor, daha fazla göndermesi gerekiyor. O yüzden herkes WAHA'dan gelip tercüman istiyor. Şimdi WAHA'da da 1 tercüman var, yetmiyor. (Tuğba, 28, Evli, İzmir)

Memnunum ama yeterli değil. Çocuklar küçük olduğu için masrafları çok. (Gül, 28, Evli, Konya)

Memnunum ama daha çok olmalı. Faturalar var, çünkü çok pahalı patates, salatalık falan. Önceden pazardan kalanları alıyordum ücretsiz. Şimdi taşındığım için pazardan ücretsiz alamıyorum. Pazar başka mahallede gidemiyorum. (Hayriye, 40, Kocası Ölmüş, Konya)

Görüşmeler kapsamında STK'lardan hizmet alan mülteci kadınlara STK'lardan ne tür beklentileri olduğuna dair sorular sorulmuştur. Mülteci kadınlar STK'lardan beklentilerini anlatırken birden fazla beklentiden bahsetmişleridir ve ortaya çıkan sonuç mülteci kadınların hizmet aldıkları STK'lardan en çok ekonomik destek beklediklerini ortaya koymuştur (Şekil 14). Bu beklentinin mülteci kadınların belirttikleri temel sorunlarla da ilişkili olduğu gözlemlenmiştir, zira kadınlar Türkiye'de yaşadıkları en temel sorun olarak ekonomik sıkıntılara değinmiş ve STK'lardan en temel beklentilerinin bu yönde olduğunu belirtmişlerdir. Beklenilen ekonomik destek hem aynî hem nakdi olarak ortaya 
çıkmakta ve kadınların STK'lardan ekonomik beklentilerinin çoğunu maddi destek oluşturmaktadır. Buna ek olarak, iş bulunması konusunda da mülteciler destek beklemektedir. Mülteci kadınların demografik bilgilerinin verildiği önceki bölümlerde gelir ve çalışma durumları konusunda kadınların Suriye'de yaptıkları meslekleri sürdürememeleri, çoğunun çalışmaması, çalışanların da çoğunlukla düşük ücretli ve evde çalıştığ1 aynı şekilde eşlerinin de çoğunlukla düşük ücretli işlerde çalıştığı ve görüşülenlerin önemli bir kesiminin gelirlerinin yetmediğini söylemesi STK'lardan en büyük beklentilerinin ekonomik içerikli olmasını açıklamaktadır.

Şekil: 14

\section{Hizmet Alan Katılımcıların STK'lardan Beklentileri}

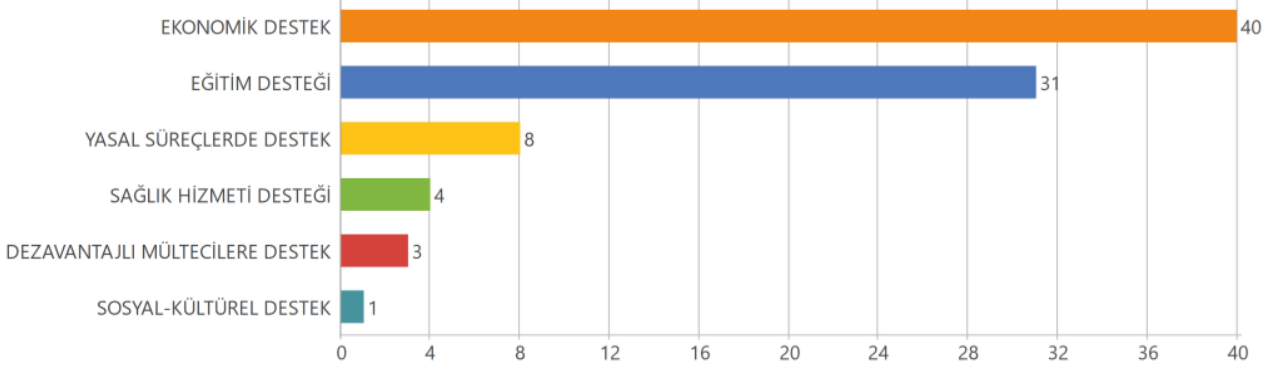

Mültecilerin destek beklediği ikinci önemli bir konu ise, eğitim başlıği altında toplanmıştır. Bu başlık altında kadınlar en çok Türkçe öğrenmeye yönelik taleplerini dile getirmişler, kursların sayısının arttırılması ve çocuklara da yönelik olması gibi taleplerini belirtmişlerdir. Dil kurslarını takip eden ikinci büyük eğitim talebi ise meslek edinmeye yönelik kuaförlük, terzilik gibi kursların sayılarının arttırılması ya da açılmasıdır. Çocuklar için ders takibi kursları açılmasını istediğini, çocuklarının Türkiye okuluna gittiğini ama kendilerinin Türkçe bilmediğini ve o yüzden çocuklara yardımcı olamadıklarını, derslerini takip edemediklerini söyleyerek, çocukların daha iyi Türkçe öğreneceği, ödevlerine yardımcı kurslar açılmasını istediğini belirten katılımcı bu durumu şöyle ifade etmiştir:

Çocuklar için ders takibi kursları açılması. Çocuklar Türkiye okuluna gidiyor ama biz Türkçe bilmiyoruz, çocuklara yardımcı olamıyoruz, derslerini takip edemiyoruz. Türk öğrenciler 1 saatte ödevi yapıyor, bizimkiler tüm gün uğraşıyor. Türklerle aynı seviye değil ama bizim çocuklar da iyi olmayı hak ediyor. (Begüm, 36, Boşanmış, Gaziantep)

Mülteci kadınlar aynı zamanda Türkiye'de bir takım yasal haklara ulaşmakta ya da yasal işlemlerini yürütmekte sıkıntılar yaşadıklarını, kimlikle ilgili sorunların çözülmesinde başka bir ülkeye göçmenlik başvurusu yapmaya kadar pek çok bürokratik işlemde STK'lardan destek beklediklerini belirtmişlerdir. 
STK'lardan beklentiler konusunda vurgu yapılan diğer bir önemli konu ise sağlık hizmetleridir. Bu konuda da göçmenler sağlı merkezlerinin iyileştirilmesi gibi yapısal sorunlardan, doğrudan tıbbi destek ve sağlık hizmetlerine erişim saatleri gibi sağlık alanında tek bir çatı altında toplanması gibi konularda STK'lardan beklenti içerisindedirler. Bir Suriyeli kadın durumu şöyle ifade etmiştir: "kadınlar için doktor 1 saat gelip gidiyor, bana sıra gelmeden gidiyor doktor. Doktorun burada daha fazla kalmasını isterim”. (Pınar, 30, Evli, Gaziantep)

Genel olarak mültecilerin STK'lardan beklentileri değerlendirildiğinde, beklentilerin az sayıda konu başlığı altında toplanmasının güç olduğu, mültecilerin sorunlarının büyük olmasından ötürü STK'ların ekonomik, yasal ve sosyal sınırlarının ötesine uzanan beklentilerin var olduğu görülmektedir.

\section{STK’lara göre Suriyeli Mülteci Kadınların Sorunları ve İhtiyaçları}

Suriyeli mülteci kadınlar ve STK temsilcilerinin mülteci kadınların sorunlarını ve ihtiyaçlarını tanımlama noktasında bir takım farklılıklar bulunduğu gözlemlenmiştir. İlk olarak, mülteciler toplumsal cinsiyete ilişkin pek çok meselenin (örneğin eğitime ve istihdama erişim) temel bir sorun olarak karşılarına çıktığını öne sürseler de kadın olmaktan kaynaklı temel sıkıntılar yaşadıklarından bahsetmemekte, kadın olmaktan kaynaklı sıkıntılar ise STK temsilcileri, özellikle de kadınlara yönelik hizmet veren STK'lar için en önemli sorunlardan biri olarak belirtilmektedir (Şekil 15). KAMER ve SGDD Konya'da çalışan iki kişi kadınlık deneyiminin ortaklığına anlatılarında şu şekilde yer vermişlerdir:

Aslında bu genel bir kadın problemi. Savaşta en çok zarar gören kadın ve çocuklar oldu. Genel konuşuyorum. Çevremde gördüklerime dayanarak söylüyorum. (Gülse, 28, Profesyonel çalışan, Kamer)

Türkiye'de mülteci olmayan diğer her kadının yaşadığı sorunları yaşıyorlar zaten. Ekstra yabancı uyruklu oldukları için zaten ben ona işte bir erkeklik şeyi var işte zaten yabancı uyruklu şikâyet edemez, ben burada polisleri tanıyorum, ben buranın vatandaşıyım, ben daha güçlüyüm. (Elif, 24, Profesyonel çalışan, SGDD Konya)

Şekil: 15

\section{STK Temsilcisi Katılımcılara Göre Suriyeli Mültecilerin Sorunları}

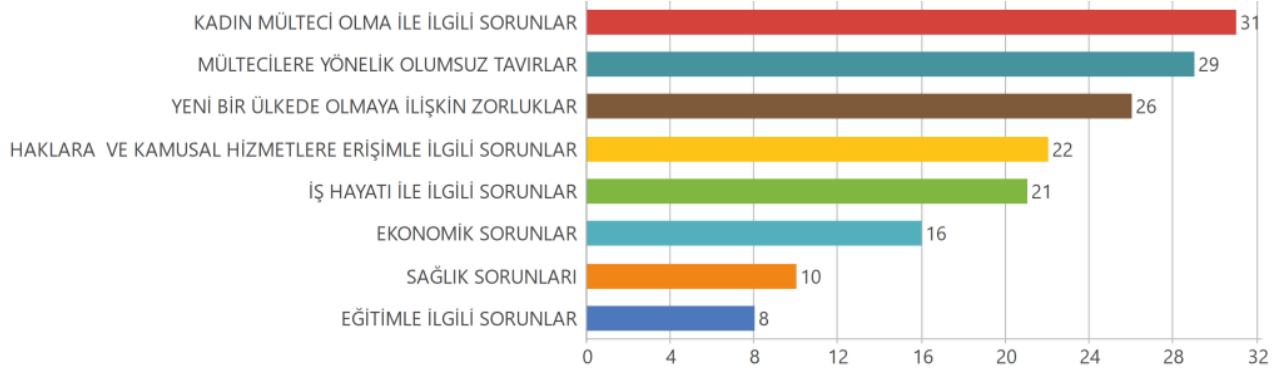


Özgür-Keysan, A. \& B. Şentürk (2021), "Sorunlar ve Beklentilerin Algılanmasında

Kadın Mülteciler ve Sivil Toplum Kurulușları”, Sosyoekonomi, 29(48), 343-376.

STK temsilcileri kadın mülteci olma ile ilgili sorunları mültecilikle birleşen ama bu durumun daha ötesine uzanan ve toplumsal cinsiyet rejimi içindeki kamu ve özel hayatta toplumsal cinsiyete dayalı eşitsiz güç dağılımı ile doğrudan alakalı olan meselelerden bahsetmiş̧lerdir. Çocuk yaşta evlilik, kumalık, aile içi planlamada söz sahibi olamama ve aile içi şiddet gibi aile ve evlilik kurumu temelinde şekillenen sorunlar STK temsilcilerinin mülteci kadınların kadın olma ile ilgili sorunlarının temel zeminini oluşturmaktadır. SGDD Gaziantep'te faaliyet gösteren Çiğdem, kumalığın mülteci kadınların hayatlarına etkisini anlatırken STK'ların bu konudaki tavırlarının kadınlar üzerinde ikincil bir baskıya dönüşebilme potansiyelini şu şekilde anlatmıştır:

Öncelikle şöyle bir sıkıntı var. Kuma sistemi. Kimsesiz kadınlar yalnız yaşayamadıkları için kuma olabiliyorlar, satılabiliyorlar, mecbur olarak kendilerini pazarlayabiliyorlar. Savaş travması yaşamış psikolojik olarak çökmüş bir kadın burada ikinci bir travma daha yaşıyor. Çünkü aynı mahalle sistemini Suriyeliler burada da devam ettiriyor. Zaten yerleşim yerleri aynı. Mesela oradaki mahalledeki bir kadın dulsa o dedikodu Suriye'de nasılsa Türkiye'de de devam ettiriliyor. Kadının yaşadığı toplumsal baskı Türkiye'de de aynı şekilde devam ediyor. Hatta belki de kat be kat fazlası. Çünkü bir yerde bizden de baskı görüyorlar. Türkiye'de kumalık yasak neden böyle bir şey yapıyorsun dediğimizde kadın bizden de aynı baskıyı görüyor. Ayrılsam nereye gideceğim çocuklarım var. Ya da tek başınayım evlenmeden nasıl yapacağım. (Çiğdem, 25, Profesyonel çalışan, SGDD Gaziatep)

STK temsilcileri kadın olmaktan kaynaklı sorunları anlatırken ikincil olarak başvurdukları çerçeve ise cinsellik alanında şekillenen taciz, istismar ve seks işçiliği gibi sorunlardır. Adana SGDD'de çalışan Sevda'nın ve KAMER'de çalışan Emine'nin anlatısı, tacizin mülteci kadınların kamusal hayata ve iş hayata katılımı üzerindeki olumsuız etkisini ve mülteci kadınların tacizi yerli kadınlardan farklı deneyimlediğini gösterir niteliktedir:

Kadın dışarı çıktığında, burada yaşayan yerli erkeklerin bakışlarından bile rahatsız olduklarını söylüyorlar. Çünkü burada mülteci olduğumuzu biliyorlar diyorlar, biliyorsunuz Türkiye'nin az çok durumunu, bakışlarından bile sözlü taciz ve devamı oluyor. (Emine, 29, Profesyonel çalı̧̧an, KAMER)

Tacize uğruyorlar iş yerinde. Nasılsa kendini anlatamıyor, nasılsa ne yapacağını bilmiyor diye o yüzden tacize uğruyorlar. Mesela Türkiye'den bir kadın yaşasa bunu ben gidip şikâyet edebilirim, anlatabilirim diyebilir. Ama Suriyeli dil bilmeyen kadın bunu yapamaz. Biri laf atsa sen ne yapıyorsun diyemez. (Sevda, 25, Profesyonel çalışan, Adana SGDD).

STK temsilcileri mültecilerin kadın olmakla ilişkili sorunlarını tanımlarken bu sorunların yerli kadınlar tarafından yaşanmasının yanı sıra mülteciliğin kadınlıkla kesişiminin bu sorunları artırdığının da vurgusunu yapmışlardır. STK temsilcilerinin ortaklaştığı bu argümana ek olarak bazı görüşmelerde "kültür" ve "değerler" kavramıyla somutlaştırılan ve Suriye ve Türkiye'deki toplumsal cinsiyet rejimlerinin farklılığına vurgular da mevcuttur: 
Özgür-Keysan, A. \& B. Şentürk (2021), "Sorunlar ve Beklentilerin Algılanmasında

Kadın Mülteciler ve Sivil Toplum Kuruluşları”, Sosyoekonomi, 29(48), 343-376.

Benim yaşadığım, Suriyelilerle çalışıyorsun onların zaten birtakım değerleri var. Buradan çok farklı, bizde çocuk işte kızlar erken yaşta evlendirilir biz hep bunların üzerine çalışıyoruz. [...] Onların şeyleri çok farklı, kalıplaşmış yargıları var, onları kırmaya çalışıyoruz. Onlar sıkıntı. Onları kırsak bile sistemle ilgili sıkıntı çok, o yüzden en çok benim şu ana kadar yaşadığım en büyük zorluk o [...] Ya da çocuklarını okutmuyorlar. Bir kere bu, kadın da erkek de iş bulamayınca çocuk işçiliğinin önüne geçemiyorsun. Çoğu ailede çocuk üzerinden geçim sağlanıyor. (Yıldız, 25, Gönüllü, İMD)

Çok sayıda erken evlilikle karşılaşabiliyoruz. Bunu aile normalleştirmiş biçimde. Belki bunu kültürünün bir parçası olarak gördüğü için filan. Bunu biz Türkiye’deki kanunlar bakın 18 yaşının altındaki herkes çocuktur ve çocuklar evlenemezler. Ergen olmadan bu iş olmaz bunu anlatmaya çalışıyoruz. Bu bir suçtur diye anlatıyoruz. Bununla başa çıkmak biraz zor çünkü bunun bir suç olduğunu o gözle bakmıyorlar. (Elif, 24, Profesyonel çalışan, SGDD Konya)

İki katılımcı grubun mülteci kadınların sorunlarını ve ihtiyaçlarını açıklamasındaki ikinci temel büyük farklılık ise ekonomik ihtiyaçlar konusundadır. İki grup katılımcı için de ekonomik temelli sorunlar Suriyeli mülteci kadınların Türkiye'de hayatlarını zorlaştıran başat meseleler arasında yer alsa da hem bu meselenin derecelendirilmesinde hem de boyutlandırılmasında temel farklılıklar gözlemlenmiştir. Suriyeli mülteci kadınların Türkiye'deki ihtiyaçlarına yönelik ifadelerinde, ilk sırada ekonomik ihtiyaçlar gelirken Şekil 4'te de gözlemlenebileceği üzere STK temsilcilerinin gözünde bu çok daha arka sıralara ilerlemiştir. Boyutlandırma açısından ise, STK temsilcileri mültecilerin yaşadıkları ekonomik problemleri temel olarak iş piyasasındaki ayrımcılıklarla ilişkilendirirken, Suriyeli mülteci kadınlar ekonomik temelli yaşanan zorlukları iş piyasasındaki ayrımcılık ve düşük ve ücretleri de kapsayarak tercüman ücretlerinin yüksekliği, faturalar ve ev kirasının ödenmesi, çocukların okul ihtiyaçlarının ve küçük bebek ve hastaların özel ihtiyaçlarının karşılanmasına kadar uzanan geniş bir çerçevede tanımlamaktadırlar.

STK'ların gözünden Türkiye'de mültecilere yönelik sorunlar mültecilerin sorunları arasında ikinci sıradadır ve STK temsilcileri kendi ihtiyaçlarından bahsederlerken bile medyadaki ayrımcı dilin ve kurumların mültecilere yönelik olumsuz algılarının kırılmasının önemli olduğunu belirtirmişlerdir. Öte yandan Suriyeli mülteciler kendilerine yönelik ayrımcı tavrı genel olarak yalnızca iş piyasasındaki ayrımcılıklar üzerinden anlamlandırmakta, kısmen komşularıyla ilişki geliştirmekte zorlandıklarını belirtseler de bu duruma Türkiye'de karşılaştıkları önemli sorunlar çerçevesinde değinmemektedir.

STK çalışanlarına yaşanan sorunların çözümü noktasında sivil toplum kuruluşlarını nerede gördükleri sorulduğu zaman verilen cevapların temel olarak Dönüştürücü Rol, Tampon Görevi ve Yetersiz Kalma olmak üzere üç ana temada toplandığı görülmektedir. Katılımcılar en çok kurumlararası ve/veya mültecilerle kurumlar arası ilişkilerin yürütülmesi ve devletin eksik kaldığı alanları doldurmakla tanımladıkları tampon görevi görüldüğünü söylemişlerdir. 
Özgür-Keysan, A. \& B. Şentürk (2021), "Sorunlar ve Beklentilerin Algılanmasında

Kadın Mülteciler ve Sivil Toplum Kurulușları”, Sosyoekonomi, 29(48), 343-376.

Haklara erişim konusunda bir boşluğu doldurduğunu düşünüyorum STK'ların aslında. Aslında kamu kurumları anlamında da çok ani bir kriz ile karşılaşıldı. Hiç bu kadar kitlesel bir göç ile karşı karşıya kalınmamıştı. ... Ama biz o anlamda kamu kurumları ile daha güzel iş birliği yürüttük. Daha olumlu dönüşler alabildik. Hassas konuları bildirdiğimiz zaman destekleri oldu. $\mathrm{O}$ anlamda güzel bir iş birliği yürüttük ve mülteciler de kamu kurumlarına nazaran biraz daha belki rahat yaklaşabiliyorlar topluma. Gelip derdini daha rahat anlatabiliyorlar. Kamunun resmi yüzü vardır ya, onu STK'lar biraz daha dengeliyor veya bizim vasıtamızla ulaşmak belki biraz daha güven veriyor onlara. Kendisi de belki gidip karakola şikâyette bulunabilir veya kimliği için başvuruda bulunabilir (Selin,36, Profesyonel Çalışan, SGDD Adana).

Katılımcıların yarıya yakını STK'ların dönüştürücü rolleri olduğundan da bahsetmiş, bu açıdan STK'ların ön yargıları kırmak, bilinçlendirmek, mültecileri güçlendirmek, sosyal uyum ve toplumsal cinsiyet hassasiyetinin oluşmasına katkıda bulunmak gibi roller olduğundan bahsetmişlerdir... Örneğin bir STK temsilcisi durumu şu şekilde özetlemiştir “....STK'lar aslında bu kaynaştırmayı ve ön yargılı olma halinin geride bırakılmasını sağlama konusunda çalışmalar yapıyor." (Emine, 29, Profesyonel Çalışan, KAMER). Katılımcıların üçte birinden fazlası da STK'ların rollerinin yetersiz olduğundan bahsetmiş̧ir. Bu noktada STK çalışanları sorunların çok büyük ve yaygın olduğu ve STK'ların özellikle kaynak yetersizliğinden ötürü etkilerinin sınırlı kaldığını belirtmişlerdir.

\section{Sonuç}

Bu çalışma, İstanbul, İzmir, Konya, Adana ve Gaziantep olmak üzere Türkiye'nin beş ayrı ilinden 64 STK temsilcisi ve 83 Suriyeli mülteci kadın ile Mayıs-Ekim 2018 tarihleri arasında gerçekleştirilen derinlemesine görüşmelerin analizine dayanarak, Türkiye'de şehirlerde yaşayan mülteci kadınların kendi sorun, ihtiyaç ve beklentileri hem kendi hem de STK'ların gözünden anlamayı amaçlamıştır. Bu anlamda mülteciler ve STK temsilcilerinin problem tanımlarının ne ölçüde ve hangi şekillerde birbiri ile örtüştüğünü ya/ya da farklılaştığını ortaya koymayı hedeflemiştir. Bu hedef doğrultusunda seçilen feminist yöntem, göçmenlik ve kadınlığın kesişimi doğrultusunda toplumsal hayatın farklı alanlarında çifte dezavantajlı konumda olan Türkiye'de yaşayan Suriyeli kadınların kendi ihtiyaçları ve sorunları konusunda seslerini duyurmayı sağlamıştır. Söz konusu grubun ihtiyaçlarını karşılamaya çalışan kurumların, politika yapıcıların ve bu konuya odaklanan araştırmacılar ve Suriyeli kadınlar yararına bilgi üretilmeye çalışılmıştır.

Görüşme yapılan Suriyeli mülteci kadınlar STK'lardan beklentilerini anlatırken birden fazla beklentiden bahsetmişlerdir ve ortaya çıkan sonuç mülteci kadınların hizmet aldıkları STK'lardan en çok ekonomik destek beklediklerini ortaya koymuştur. Beklenilen ekonomik destek hem aynî hem nakdi olarak ortaya çıkmakta ve kadınların STK'lardan tüm beklentilerinin büyük çoğunluğunu maddi destek oluşturmaktadır. Kadınlar temel ihtiyaç kategorisinde yer alan ekonomik ihtiyaçları ve sonrasında eğitim ve sağlı alanına dair ihtiyaçlarını dile getirmişlerdir. Buna ek olarak, iş bulunması konusunda da mülteci kadınlar destek beklemektedir. Bu bağlamda, derneklerin faaliyetlerinin en büyük kısmını oluşturan 
Özgür-Keysan, A. \& B. Şentürk (2021), "Sorunlar ve Beklentilerin Algılanmasında

Kadın Mülteciler ve Sivil Toplum Kuruluşları”, Sosyoekonomi, 29(48), 343-376.

eğitimler vb. aktiviteler kadınlar için çok faydalı olsa da en büyük ihtiyaçlarını ekonomik olarak tanımlayan kadınlar için bu durum ikincil bir konu olarak kalabilmektedir. Ayrıca Çoğu Suriyeli mülteci kadın, "destek" kavramını ekonomik olarak algılamakta ve tanımlamaktadır ve bu durum STK'lardan temel beklentinin ekonomik olduğunu göstermektedir. Diğer bir deyişle, mülteci kadınlar STK'ların kadınların güçlenmesini hedefleyen dil kursları, meslek edindirme kursları, yasal haklar hakkında bilgilendirme, sağlık hizmetlerine erişimde destek gibi hizmetler alsalar da kadınların gözünde ilk verilmesi gereken desteğin ekonomik olduğu görüşmelerde ortaya çıkmıştır.

$\mathrm{Bu}$ durum bize göstermektedir ki STK'lar ile mülteci kadınların sorunları algılamasında bir makas bulunmaktadır. STK'ların faaliyetleri ile Suriyeli mülteci kadınların talep ve ihtiyaçları tam olarak örtüşmemektedir. Diğer bir deyişle Suriyeli mülteci kadınlar STK'lardan beklentilerini anlatırken birden fazla beklentiden bahsetmişlerdir ve ortaya çıkan sonuç, mülteci kadınların hizmet aldıkları STK'lardan en çok ekonomik destek beklediklerini ortaya koymuştur. Beklenilen ekonomik destek hem aynî hem nakdî olarak ortaya çıkmakta ve kadınların STK'lardan tüm beklentilerinin büyük çoğunluğunu maddi destek oluşturmaktadır. Görüşme yapılan kadınların çoğu evli olmasına rağmen $(\% 65,1)$, kocası ölmüş kadınlar $(\% 15,7)$ en büyük ikinci kategoriyi oluşturmaktadır. Kocası ölmüş, boşanmış, bekâr, kocası kayıp kadınların toplam oranı ise örneklemimizin üçte birini $(\% 34,9)$ kapsamaktadır. Suriyeli kadınların iş gücüne katılımının çok az olduğu göz önünde bulundurulduğunda, örneklemimizde yer alan kadınların üçte biri geçinmek için yardıma bağımlıdır. Evli olan kadınlar da ekstra ekonomik olarak desteğe ihtiyaç duymaktadır. Zira devlet tarafından Kızılay aracılığıyla sunulan yardım paketi yetersiz kalmaktadır. Görüşülen kadınların \% 71'i aylık hane gelirinin 2000 TL ve altı olduğunu belirtmiştir. Ayrıca hanelerde çalışmayan erkek sayısı da yüksektir. 83 katılımcı içinde 14 katılımcı eşinin çalışmadığını ifade etmiştir. Eşleri çalışan kadınların büyük çoğunluğu ise, eşin sıklıkla iş değiştirdiğini, genellikle geçici ve güvencesiz işlerde çalıştıklarını belirtmiştir. Bu veriler Suriyeli kadınların en temel probleminin ekonomik sıkıntı olduğuna işaret etmektedir. Bu durumda herhangi bir STK kendileri ile iletişime geçtiğinde veya kadınların kendileri STK'ların varlığından haberdar olup iletişime geçtiklerinde öncelikli beklentileri ekonomik destek olmaktadır. İnanç ve yardım temelli faaliyet gösteren hayırsever kurumların varlığı da Suriyeli kadınlar kendilerine hizmet ve destek sunan kurumların aynî ve maddi destek sunma kapasitesine sahip olacağı yönündeki beklentilerini pekiştirmektedir. Buna ek olarak, iş bulunması konusunda da Suriyeli mülteci kadınlar destek beklemektedir. Bu bağlamda, derneklerin faaliyetlerinin en büyük kısmını oluşturan eğitimler vb. aktiviteler kadınlar için çok faydalı olsa da en büyük ihtiyaçlarını ekonomik olarak tanımlayan kadınlar için bu durum ikincil bir konu olarak kalabilmektedir. Kadınlar görüşmelerde güçlenme kavramına değinseler de temel ihtiyaç kategorisinde yer alan ekonomik ihtiyaçları ve sonrasında eğitim ve sağlık alanına dair ihtiyaçlarını dile getirmişlerdir.

Mülteci kadınların ekonomik ihtiyaçlarının karşılanmasının STK'lardan beklemesi problemli bir durumdur. Faaliyetleri açısından değerlendirildiğinde STK'lar kadınların ekonomik beklentileri içinde tanımladıkları maddi/aynî destek ve meslek edindirme gibi misyon taşısalar da bu beklentileri karşılamakta yetersiz kalabilmektedirler. Literatürde var 
Özgür-Keysan, A. \& B. Şentürk (2021), "Sorunlar ve Beklentilerin Algılanmasında

Kadın Mülteciler ve Sivil Toplum Kuruluşları”, Sosyoekonomi, 29(48), 343-376.

olan çalışmaların bizlere de gösterdiği gibi STK'lara toplumsal kabul ve uyum süreçlerinde büyük roller düşmektedir (Erdoğan, 2015; Erdoğan, 2015a; Çebi, 2017). STK'lar kısıtlı düzeyde olsa da mültecilerin ekonomik düzlemdeki ihtiyaçlarını tespit edebilirler (BM Kadın Birimi ve SGDD, 2018) fakat insan kaynaklarının çoğu zaman yetersiz kaldığı ve özellikle hibe ve fonlarla çalışmalarını sürdüren STK'ların bu alandaki desteklerinin gün geçtikçe azalmasına ve istikrarlı olmamasına dikkat çeken çalışamaların da varlığını düşündüğümüzde (Kutlu, 2015; İGAM, 2013) STK'ların ekonomik destek sağlayan yapılar olarak görülmesini sorgulamamızı, yapabilirlik ve kapasitelerini tartışmamızı ve sosyal devlet olarak devlete önemli görevleri düştüğünü hatırlatmaktadır.

Ekonomik iyileşmeyi içeren ancak bunun çok ötesine geçen kadınların güçlenmesi kavramı bilindiği gibi, literatürde çok farklı şekillerde tanımlanmakla birlikte, bu kavram temel olarak "kadınların kendi potansiyel güçlerinin farkına varmaları ve güçlerini yeniden ve dönüştürücü bir şekilde tanımlamaları ve kullanmaları” olarak ifade edilmektedir (Buz, 2007: 47; Ette, 2007). STK'ların değinilen sınırlı kapasiteleriyle ekonomik destek verme potansiyellerinin kadınların beklediği ölçüde mümkün olmamasının yanı sıra STK'ların çeşitli hizmetlere erişme, meslek edinme, haklara ulaşım konusunda kadınlara destek olarak yapabilirliklerini arttırdığını ifade edilebiliriz (Aras \& Duman, 2018). Bizim çalışmamızda da ortaya çıktığı şekilde Türkiye'de yaşayan Suriyeli kadınlar ailelerine destek sağlama, eğitim alma ve diğer amaçlarla STK'lara gidebilmekte bu durumla beraber kadınların tek başlarına dışarı çıkması aile ve komşular gibi birincil temaslar dışındaki kişilerle de sosyalleşmesi mümkün olabilmektedir. STK'ların varlığının bu tip aktiviteler için ciddi bir motivasyon ve meşruluk kaynağı teşkil ettiği gözlemlenmiştir. Öte yandan geleneksel bağların görece çözümlenmiş olması kadınların komşular, akrabalar ve yaşam alanının paylaşıldığı diğer kişilerin gözetiminden ve denetiminden uzak kalabilmesini sağladığı ve bu sayede de hem ev içindeki toplumsal cinsiyet ilişkileri dengesinin kendi lehlerine bozulduğu hem de kamusal görünürlük anlamında daha az baskıyla karşılaştıkları anlaşılmıştır. Yine aynı şekilde STK'lar kadınlar için geleneksel ağlar dışında ilişkilerin kurulabileceği güvenli bir alan olmakta, kadınların güçlenme sürecinde temel ve vazgeçilmez bir aracı konumda bulunmaktadır. Son olarak da yine bu çalışmanın verilerine dayanarak STK'lar aracılığıyla kadınların güçlenmesinin:

- Meslek edindirme kurslarına katılım imkanlarının artırılması,

- Dil kursu imkanlarının artırılması ve devamlılığının sağlanması,

- Kadınların bir araya gelmesini sağlayan konularda sosyal faaliyetlerin artırılması,

- Yerel toplum ve kadın mülteciler ile ortak konular üzerinden ortak katılımlı sosyal faaliyetler düzenlemesi,

- Yasal haklar, sağlık hakları ve uygulamaları hakkında bilgilendirme faaliyetlerinin artırılmasi,

- Derneklerde çocuk oyun odalarının olması ve yine küçük çocuklar için ücretsiz bakım hizmetlerinin -kreş vs.- sağlanması,

- STK'ların kadın mülteci gruplarına misyon ve vizyonlarını daha açık ifade etmeleri, 
Özgür-Keysan, A. \& B. Şentürk (2021), "Sorunlar ve Beklentilerin Algılanmasında

Kadın Mülteciler ve Sivil Toplum Kuruluşları”, Sosyoekonomi, 29(48), 343-376.

- STK'ların kadın mültecilere dair ihtiyaç tespit ve analizlerini düzenli olarak tekrar etmeleri,

- STK'lar arası "en iyi" sonuç veren ve etki yaratan program ve aktivitelerin paylaşılması aracıllğıyla mümkün olabileceği öne sürülebilir.

\section{Kaynaklar}

AFAD (2014), "Türkiye'deki Suriyeli Kadınlar", <https://www.afad.gov.tr/upload/Node/3932/xfiles/turkiye_deki-suriyeli-kadinlar_2014.pdf>, 08.12.2019.

Akbaş, E. (2012), "Göçmenler Arasındaki Dayanı̧macı Ağların Dönüşümü Göçmen Sivil Toplum Örgütlerinin Yeni Misyonu”, içinde: (der. S.G. Ihlamur-Öner \& Ş. Öner) Küreselleşme Çă̆ında Göç, İstanbul: İletişim Yayıncılık.

Aksurmeli, M. \& Z.S. Tekten (2016), "İnanç Temelli Organizasyonlar ve Toplumsal Birlik: Konya Örneği”, içinde: (der. M. Çınar \& H.İ. Karaarslan \& İ.H. İlgi) Toplumsal Birliğin Güçlendirilmesinde Dini Söylemin Önemi, İstanbul: Ensar Neşriyat.

Al-Rousan, T. \& Z. Schwabkey \& L. Jirmanus \& B.D. Nelson (2018), "Health needs and priorities of Syrian refugees in camps and urban settings in Jordan: perspectives of refugees and health care providers", Eastern Mediterranean Health Journal (EMHJ), 24(3), 243-254.

Ambrosini, M. \& J. Van der Leun (2015), "Introduction to the Special Issue: Implementing Human Rights: Civil Society and Migration Policies", Journal of Immigrant \& Refugee Studies, 13(2), 103-115.

Ambrosini, M. (2013a), "We are against a multi-ethnic society': Policies of exclusion at the urban level in Italy", Ethnic and Racial Studies, 36(1), 136-155.

Ambrosini, M. (2013b), "Fighting discrimination and exclusion: Civil society and immigration policies in Italy", Migration Letters, 10(3), 313-323.

Ambrosini, M. (2015), "NGOs and Health Services for Irregular Immigrants in Italy: When the Protection of Human Rights Challenges the Laws", Journal of Immigrant \& Refugee Studies, 13(2), 116-134.

Aras, B. \& Y. Duman (2018), "I/NGOs' Assistance to Syrian Refugees in Turkey: Opportunities and Challenges", Journal of Balkan and Near Eastern Studies, 21(4), 478-491.

Aslan, M. \& J.W. Yılmaz (2019), "Pathways towards Social Inclusion of Refugees in Turkey", $<$ http://turkishpolicy.com/article/955/pathways-towards-social-inclusion-of-refugees-inturkey>, 08.12.2019.

Ballarino, G. \& N. Panichella (2018), "The occupational integration of migrant women in Western European labour markets", Acta Sociologica, 61(2), 126-142.

Barın, H. (2015), “Türkiye'deki Suriyeli Kadınların Toplumsal Bağlamda Yaşadıkları Sorunlar ve Çözüm Önerileri”, Göç Araşttrmaları Dergisi, 1(2), 10-56.

Bastia, T. \& N. Piper (2019), "Women migrants in the global economy: A global overview (and regional perspectives)", Gender \& Development, 27(1), 15-30.

BM (t.y.) Insani Yardlm, <http://www.unicankara.org.tr/today/5.html>, 08.12.2019. 
Özgür-Keysan, A. \& B. Şentürk (2021), "Sorunlar ve Beklentilerin Algılanmasında Kadın Mülteciler ve Sivil Toplum Kuruluşları”, Sosyoekonomi, 29(48), 343-376.

BM Kadın Birimi \& SGDD (2018), Türkiye’de Geçici Koruma Altındaki Suriyeli Kadın ve Kız Çocukların İhtiyaç Analizi, <http://eca.unwomen.org/en/digital-

library/publications/2018/08/needs-assessment-of-syrian-women-and-girls-undertemporary-protection-status-in-turkey>, 08.12.2019.

Boserup, E. (1970), Women's role in economic development, London: Allen \& Unwin.

Boyd, M. \& E. Grieco (2003), "Women and migration: Incorporating gender into international migration theory", Migration Information Source, 1(35), 28.

Buz, S. (2007), “Göçte Kadınlar: Feminist Yaklaşım Çerçevesinde Bir Çalışma”, Toplum ve Sosyal Hizmet, 18(2), 37-50.

Cankurtaran, Ö. \& H. Albayrak (2019), From Syria to Turkey: Being a Woman, Ankara: Merdiven Publishing.

Castle, S. vd. (2014), The age of migration: International population movements in the modern world, (5. Basim), Houndmills: Palgrave Macmillan.

Clarke, G. (1996), "Non-Governmental Organizations (NGOs) and Politics in the Developing World", Papers in International Development 20, Swansea: Centre for Development Studies, 1-25.

Çebi, E. (2017), "The role of Turkish NGOs in social cohesion of Syrians", Turkish Journal of Middle Eastern Studies, 135-170.

Çınar, M. (1994), "Unskilled urban migrant women and disguised employment: Home-working women in Istanbul, Turkey", World Development, 22(3), 369-380.

Daley, P. (1991), “Gender, displacement and social reproduction: Settling Burundi refugees in Western Tanzania”, Journal of Refugee Studies, 4(3), 248-266.

Douglas, M. \& R. Levitan \& L. Kiama (2017), "Expanding the role of NGOs in resettlement", Forced Migration Review, 54, 35-37.

Eastman, C.L.S. (2012), Shaping the Immigration Debate: Contending Civil Societies on the USMexico Border, Boulder: First Forum Press.

Eghdamian, K. (2016), "Religious Identity and Experiences of Displacement: An Examination into the Discursive Representations of Syrian Refugees and Their Effects on Religious Minorities Living in Jordan", Journal of Refugee Studies, 30(3), 447-467.

Elbers vd. (2014), "Trust or Control? Private Cooperation at the Crossroads", Public Administration and Development, 34, 1-13.

Erden, Ö. (2016), “Building Bridges for Refugee Empowerment”, Journal of International Migration and Integration, 18(1), 249-265.

Erman, T. (2014), "Kentin kıyısında kadın olmak Gecekondudan TOKİ kentsel dönüşüm sitesine geçişte kadın deneyimleri”, içinde: (ed. F. Cantek) Kenarın Kitabı: “Ara”da Kalmak, Çeperde Yaşamak, İstanbul: İletişim Yayınları, 89-120.

Ette, M. (2007), "Empowerment”, içinde: (ed. G. Blakely \& V. Bryson), The Impact of Feminism on Political Concepts and Debates, Manchester: Manchester University Press.

Fleury, A. (2016), "Understanding women and migration: A literature review”, Knomad Workıng Paper, 8 Washington, DC, <http://www.atina.org.rs/sites/default/files/KNOMAD\%20Understaning\%20Women\%20 and\%20Migration.pdf $>, 08.12 .2019$. 
Flora-Lau, P.Y. (2019), "Empowerment in the Asylum-seeker Regime? The Roles of Policies, the Non-profit Sector and Refugee Community Organizations in Hong Kong", Journal of Refugee Studies, https://doi.org/10.1093/jrs/fez090, 0812.2019.

Friedman, A.R. (1992), "Rape and domestic violence: The experience of refugee women", Women \& Therapy, 13(1-2), 65-78.

Geddes, A. (2003), The Politics of Migration and Immigration in Europe, London: Sage.

Göç İdaresi Genel Müdürlüğü (2015), Kitlesel Akınlar, <http://www.goc.gov.tr/icerik3/kitleselakinlar_409_558_559>, 08.12.2019.

Göç İdaresi Genel Müdürlüğü (2020), İstatistikler, <https://www.goc.gov.tr/gecici-koruma5638>, 08.12.2019.

Herwig, R. (2017), "Strategies of Resistance of Syrian Female Refugees in Sanliurfa", Movements, $3(2), 179-194$.

Hsu, J. (2012), "Spaces of Civil society: The Role of Migrant Non-governmental Organizations in Beijing and Shanghai", Progress in Development Studies, 12(1), 63-76.

Hyndman, J. (2000), Managing Displacement: Refugees and the Politics of Humanitarianism, Minneapolis: University of Minnesota Press.

IGAM (2013), Sivil Toplum Örgütlerinin Türkiye'deki Suriyeli Mülteciler İçin Yaptıkları Çalışmalar ile İlgili Rapor, <http://www.igamder.org/wp-content/uploads/2012/06/Suriye-STKRaporu.pdf>, 08.12.2019.

Ihlamur-Öner, S.G. (2012), "Ulus Ötesi Göç Sürecinde Dini Ağlar ve Örgütler”, içinde: (ed. S.G. Ihlamur-Öner \& S. Öner), Küreselleşme Çağında Göç, İstanbul: İletişim Yayıncılık.

KAMER (2013), Suriyeli Göçmenler Dışarıda Kalanlar, <http://www.kamer.org.tr/icerik_detay.php?id=178>, 08.12.2019.

Kelson, G.A. \& D.L. DeLaet (1999), Gender and immigration, London: Macmillan.

Kıvılcım, Z. (2016), "Legal Violence Against Syrian Female Refugees in Turkey”, Fem Leg Stud, 24, 193-214.

Koffman, E. vd. (2005), Gender and International Migration in Europe: Employment, Welfare and Politics, London: Routledge.

Körükmez, L. vd. (2020), Mecburiyet, Müzakere, Değişim: Suryeli Kadınların Çalışma Deneyimleri ve Toplumsal Cinsiyet İlişkileri, GAR (Göç Araştırmaları Derneği) Kitap Serisi, No. 2 ISBN: 978-605-80592-2-1.

Kutlu, Z. (2015), Bekleme Odasından Oturma Odasına: Suriyeli Göçmenlere Yönelik Çalışmalar Yürüten Sivil Toplum Kuruluşlarına Dair Kısa Bir Değerlendirme, <http://aciktoplumvakfi.org.tr/medya/02062015beklemeodasi.pdf>, 08.12.2019.

Laubenthal, B. (2007), “The Emergence of Pro-regularization Movements in Western Europe", International Migration, 45(3), 101-133.

Lester, E. (2005), “A Place at the Table: The Role of NGOS in Refugee Protection: International Advocacy and Policy-making”, Refugee Survey Quarterly, 24(2), 125-142.

Letherby, G. (2003), Feminist Research in Theory and Practice, Buckingham, Philadelphia: Open University Press. 
Özgür-Keysan, A. \& B. Şentürk (2021), "Sorunlar ve Beklentilerin Algılanmasında Kadın Mülteciler ve Sivil Toplum Kuruluşları”, Sosyoekonomi, 29(48), 343-376.

Mackreath, H. \& S.G. Sağnıç (2017), Civil Society and Syrian Refugees in Turkey, Istanbul: Citizens Assembly, <http://www.hyd.org.tr/attachments/article/214/civil-society-and-syrianrefugees-in-turkey.pdf>, 08.12.2019.

Malkki, L.H. (1996), "Speechless Emissaries: Refugees, Humanitarianism and Dehistoricization", Cultural Anthropology, 11(3), 377-404.

Maynard, M. (1994), "Methods, Practice and Epistemology. The Debate about Feminism and Research", içinde: (der. M. Maynard \& J. Purvis), Researching Women's Lives from a Feminist Persective, London, Bristol: Taylor and Francis, 10-26.

MAZLUMDER (2014), Kamp Dışında Yaşayan Suriyeli Kadın Sığınmacılar Raporu, <http://mazlumder.org/webimage/MAZLUMDER\%20KAMP\%20DI\%C5\%9EINDA\%2 0YA\%C5\%9EAYAN\%20KADIN\%20SI\%C4\%9EINMACILAR\%20RAPORU(9).pdf>, 08.12.2019.

Nesteruk, O. \& L. Marks \& M.E.B. Garrison (2009), “Immigrant Parents' Concerns Regarding Their Children's Education in the United States", Family and Consumer Sciences Research Journal, 37(4), 422-441.

Nicholls, W.J. (2013), "Fragmenting Citizenship: Dynamics of Cooperation and Conflict in France's Immigrant Rights Movement", Ethnic and Racial Studies, 36(4), 611-631.

Özgür-Keysan, A. \& B. Şentürk (2020b), "Philanthropists, Professionals and Feminists: Refugee NGOs and the Empowerment of Syrian Women in Gaziantep, Turkey", International Migration, <https://onlinelibrary.wiley.com/doi/full/10.1111/imig.12728?af=R>, 08.12.2019.

Özgür-Keysan, A. (2020a), "Refugee-focused NGOs in Turkey: Difficulties and Expectations", içinde: S. Kolukırık \& E. Gün (eds.), Migration Generating Geographies and International Irregular Migrations, Berlin: Peter Lang Publishing, 129-149.

Özkan, M. (2012), "Transnational Islam, Immigrant NGOs and Poverty Alleviation: The Case of the IGMGJ”, Journal of International Development, 24, 467-484.

Öztürk, L. vd. (2019), "Challenges and Obstacles for Syrian Refugee Women in the Turkish Labor Market”, Societies, 9(3), 1-10.

Pedraza, S. (1991), "Women and Migration: The Social Consequences of Gender", Annual Review of Sociology, 17, 303-325.

Phizacklea, A. (1998), "Migration and globalization: A feminist perspective", içinde: K. Koser \& H. Lutz (eds.), The new migration in Europe, Palgrave Macmillan, London, 21-38.

Piotukh, V. (2015), Biopolitics, Governmentality and Humanitarianism: "Caring” for the population in Afghanistan and Belarus, New York: Routledge.

Pratt, G. \& B.S.A. Yeoh (2003), “Transnational (Counter) Topographies”, Gender, Place and Culture, 10(2), 159-166.

Qin, D.B. (2006), “Our Child Doesn't Talk to Us Anymore: Alienation in Immigrant Chinese Families", Anthropology and Education Quarterly, 37(2), 162-179.

Raghuram, P. (2008), "Migrant women in male-dominated sectors of the labour market: a research agenda", Population, space and place, 14(1), 43-57.

Rosenau-Williams, K. \& Z. Sezgin (2014), "Islamic Migrant Organizations: Little-Studied Actors in Humanitarian Action, International Migration Review, 48(2), 324-353. 
Sijbrandi, M. vd. (2017), "Strengthening mental health care systems for Syrian refugees in Europe and the Middle East: integrating scalable psychological interventions in eight countries", European Journal of Psychotraumatology, 8(2), 1-11.

Sun, K. \& W. Cadge (2013), "How do Organizations Respond to New Immigrants? Comparing two New England Cities”, Journal of Immigrant \& Refugee Studies, 11(2), 157-177.

Sunata, U. \& S. Tosun (2018), “Assessing the Civil Society's Role in Refugee Integration in Turkey: NGO-R as a New Typology”, Journal of Refugee Studies, 1-21.

Syed, J. \& P. Murray (2009), "Combating the English language deficit: The labour market experiences of migrant women in Australia", Human Resource Management Journal, 19(4), 413-432.

Szczepanikova, A. (2010), "Performing Refugeness in Czech Republic: Gendered Depoliticisation through NGO Assistance", Gender, Place and Culture, 17(4), 461-477.

Şentürk, B. (2015), Bu çamuru Beraber Çiğnedik, Bir Gecekondu Mahallesi Hikayesi, İstanbul: İletişim Yayınları.

Tobin, S.A. \& M.O. Campbell (2016), "NGO Governance and Syrian Refugee "Subjects" in Jordan", Middle East Report, MER278, 46.

Todd, Z. (2019), By the Numbers: Syrian Refugees Around the World, <https://www.pbs.org/wgbh/frontline/article/numbers-syrian-refugees-around-world/>, 08.12.2019.

Tomlinson, F. \& S. Egan (2002), "From marginalization to (dis)empowerment: Organizing training and employment services for refugees", Human Relations, 55(8), 1019-1043.

Van der Leun, J. \& H. Bouter (2015), "Shelter: Inclusion and Exclusion of Irregular Immigrants in Dutch Civil Society", Journal of Immigrant \& Refugee Studies, 13(2), 135-155.

Walby, S. (2016), Patriyarka kuramı, Çev. H. Osmanoğlu, Ankara, Dipnot Yayınları.

Wedel, H. (2001), Siyaset ve Cinsiyet: İstanbul Gecekondularında Kadınların Siyasal Katılımı, İstanbul: Metis Yayınları.

Wolf, D.L. (1996), "Situating Feminist Dilemmas in Fieldwork”, içinde: D.L. Wolf (ed.), Feminist Dilemmas in Fieldwork, Colorado, Oxford: Westview Press, 1-56.

Wood, E.M. (1998), Retreating from Class: The New 'True' Socialism, London, NewYork: Verso Books.

Yenilmez, M. İ. (2017), “The Impact of Forced Migration in the Middle East: Syrian and Palestinian Refugees", Perceptions, (4), 183-201.

Y1lgör, A.G. (2019), “Krizlerin toplumsal cinsiyet boyutu ile analizi”, Toplum ve Hekim, (34)3, 176181. 